\title{
Signaling pathways of genetic variants and miRNAs in the pathogenesis of myasthenia gravis
}

\author{
Kai Qian ${ }^{1, \#}$, Jia-Xin Xu ${ }^{3 \#}$, Yi Deng ${ }^{4 \#}$, Hao Peng ${ }^{2}$, Jun Peng ${ }^{2}$, Chun-Mei Ou ${ }^{5}$, Zu Liu $^{3}$, Li-Hong Jiang ${ }^{2}$, \\ Yong-Hang Tai $^{6}$ \\ ${ }^{1}$ Faculty of Life and Biotechnology, Kunming University of Science and Technology, Kunming, China; ${ }^{2}$ Department of Thoracic Surgery, Institute \\ of The First People's Hospital of Yunnan Province, Kunming, China; ${ }^{3}$ Department of Cardiovascular surgery, Yan' an Affiliated Hospital of Kunming \\ Medical University, Kunming, China; ${ }^{4}$ Department of Oncology, Institute of Surgery Research, Daping Hospital, Army Medical University, \\ Chongqing, China; ${ }^{5}$ Department of Cardiovascular surgery, Institute of the First People's Hospital of Yunnan Province, Kunming, China; ${ }^{6}$ School of \\ Electronic Information in the Yunnan Normal University, Kunming, China \\ Contributions: (I) Conception and design: K Qian, JX Xu, Y Deng; (II) Administrative support: LH Jiang, YH Tai; (III) Provision of study materials or \\ patients: K Qian, Y Deng, J Peng; (IV)Collection and assembly of data: JX Xu, CM Ou, Z Liu, H Peng; (V) Data analysis and interpretation: K Qian, \\ JX Xu, Y Deng; (VI) Manuscript writing: All authors; (VII) Final approval of manuscript: All authors. \\ \#These authors contributed equally to this work. \\ Correspondence to: Li-Hong Jiang. Department of Thoracic Surgery, Institute of the First People's Hospital of Yunnan Province, Kunming University \\ of Science and Technology, Kunming 650032, China. Email: jlh15198763375@163.com; Yong-Hang Tai. School of Electronic Information in the \\ Yunnan Normal University, Kunming, China. Email: taiyonghang@163.com.
}

Backgroundk Myasthenia gravis (MG) is a chronic autoimmune neuromuscular disorder causing muscle weakness and characterized by a defect in synaptic transmission at the neuromuscular junction. The pathogenesis of this disease remains unclear. We aimed to predict the key signaling pathways of genetic variants and miRNAs in the pathogenesis of MG, and identify the key genes among them.

Methods: We searched published information regarding associated single nucleotide polymorphisms (SNPs) and differentially-expressed miRNAs in MG cases. We search of SNPs and miRNAs in literature databases about MG, then we used bioinformatic tools to predict target genes of miRNAs. Moreover, functional enrichment analysis for key genes was carried out utilizing the Cytoscape-plugin, known as ClueGO. These key genes were mapped to STRING database to construct a protein-protein interaction (PPI) network. Then a miRNA-target gene regulatory network was established to screen key genes.

Results: Five genes containing SNPs associated with MG risk were involved in the inflammatory bowel disease (IBD) signaling pathway, and FoxP3 was the key gene. MAPK1, SMAD4, SMAD2 and BCL2 were predicted to be targeted by the 18 miRNAs and to act as the key genes in adherens, junctions, apoptosis, or cancer-related pathways respectively. These five key genes containing SNPs or targeted by miRNAs were found to be involved in negative regulation of $T$ cell differentiation.

Conclusions: We speculate that SNPs cause the genes to be defective or the miRNAs to downregulate the factors that subsequently negatively regulate regulatory $\mathrm{T}$ cells and trigger the onset of MG.

Keywords: Myasthenia gravis (MG); polymorphism; miRNAs; signaling pathway; bioinformatics

Submitted Jan 03, 2020. Accepted for publication Sep 30, 2020.

doi: $10.21037 / g s-20-39$

View this article at: http://dx.doi.org/10.21037/gs-20-39 


\section{Introduction}

Myasthenia gravis (MG) is a chronic autoimmune neuromuscular disorder causing muscle weakness and characterized by a defect in synaptic transmission at the neuromuscular junction. Currently, several autoimmune antibodies to acetylcholine receptors (AChR), musclespecific kinase (MuSK), and low molecular weight receptorrelated low-density lipoprotein-4 (Lrp4) have been demonstrated to attack the corresponding antigenic targets, leading to the onset of MG (1). However, the involved genetic and molecular mechanisms leading to the induction and production of these antibodies remain unclear.

A variety of genetic variants, e.g., -3279 and IVS9+459 in Foxp3, have been shown to be strongly associated with MG risk (2). Mutations in different genes encoding molecules important in the neuromuscular junction cause major changes in function (3). Nevertheless, several miRNAs, e.g., miR-122 and miR-185 (4) have been reported to be differentially expressed in the serum or peripheral blood mononuclear cells (PBMC) of MG patients, showing the close connections between these miRNAs and the pathophysiology of MG (5). Aberrant microRNA (miRNA) expression suggests that epigenetic modification influences $M G$ risk (4).

Genes are the core of genetics and epigenetics. The overwhelming majority of associated genes are involved in the immune system. Therefore, we presumed that some key genes targeted by these genetic variants or miRNAs, i.e., at the DNA or RNA level, are involved in some critical pathways to trigger the onset of MG. By using bioinformatics tools, we aimed to predict these key genes and signaling pathways. We present the following article in accordance with the MDAR reporting checklist (available at http://dx.doi.org/10.21037/gs-20-39).

\section{Methods}

A summary of the following steps is shown in Figure 1. The study was conducted in accordance with the Declaration of Helsinki (as revised in 2013).

\section{Global search of SNPs and miRNAs in literature databases}

To identify publications on MG and genetic variants, a comprehensive, systematic search of existing literature was first conducted. We searched the databases Medline,
PubMed and Embase, up to June $1^{\text {st }} 2019$ using the MeSH terms "Myasthenia Gravis" and "Polymorphism, Single Nucleotide (SNP)", or "Genome-Wide Association Study (GWAS)". We performed another search of the literature on MG and miRNAs, using "Myasthenia Gravis" and "miRNAs" as MeSH terms. The search strategies used are listed in Table S1. All the identified publications were dealing with blood samples in MG cases and controls. We excluded articles without full text or not in English. Two studies collected data from these articles (KQ and YD, with 7 years and 12 years of experience in MG, respectively. YD has two years of statistical work experience. Both are familiar with English).

\section{Prediction of miRNA target genes}

Target genes of these miRNAs were predicted using the bioinformatics prediction tool "miRWalk" (http://www. umm. uni-heidelberg. de/apps/zmf/mirwalk/) (6) and validated by all the other tools provided on the miRWalk website including miRanda, miRDB, RNA22, and Targetscan.

\section{Patbway enrichment analyses}

In order to identify pathways involving the genes targeted by SNPs or miRNAs, we performed enrichment analysis using online functional annotation tools, i.e., DAVID (http://david.abcc.ncifcrf.gov/, updated in May 2018) (7) and STRING (http://string-db. org/, version 10.0) (8) The top most significant pathways were confirmed by gene counts $\geq 5$, and both satisfied the Bonferroni-corrected cutoff (Bonferroni P value $<0.05$ ).

\section{Analysis of protein-protein interaction networks}

Protein-protein interaction networks (PPIs) and clusters of these proteins were verified by STRING (confidence scores $\geq 0.4$ ). The key genes were defined as those with higher degrees of connectivity in PPIs. Cytoscape was utilized to construct the protein interaction network, which was used to calculate the score of gene nodes by using three centrality methods [i.e., Degree Centrality, Betweenness Centrality, and Closeness Centrality (9-11)]. The key genes were defined as those with higher degrees of connectivity in PPIs, which were identified by a network topology analysis $(11,12)$. 


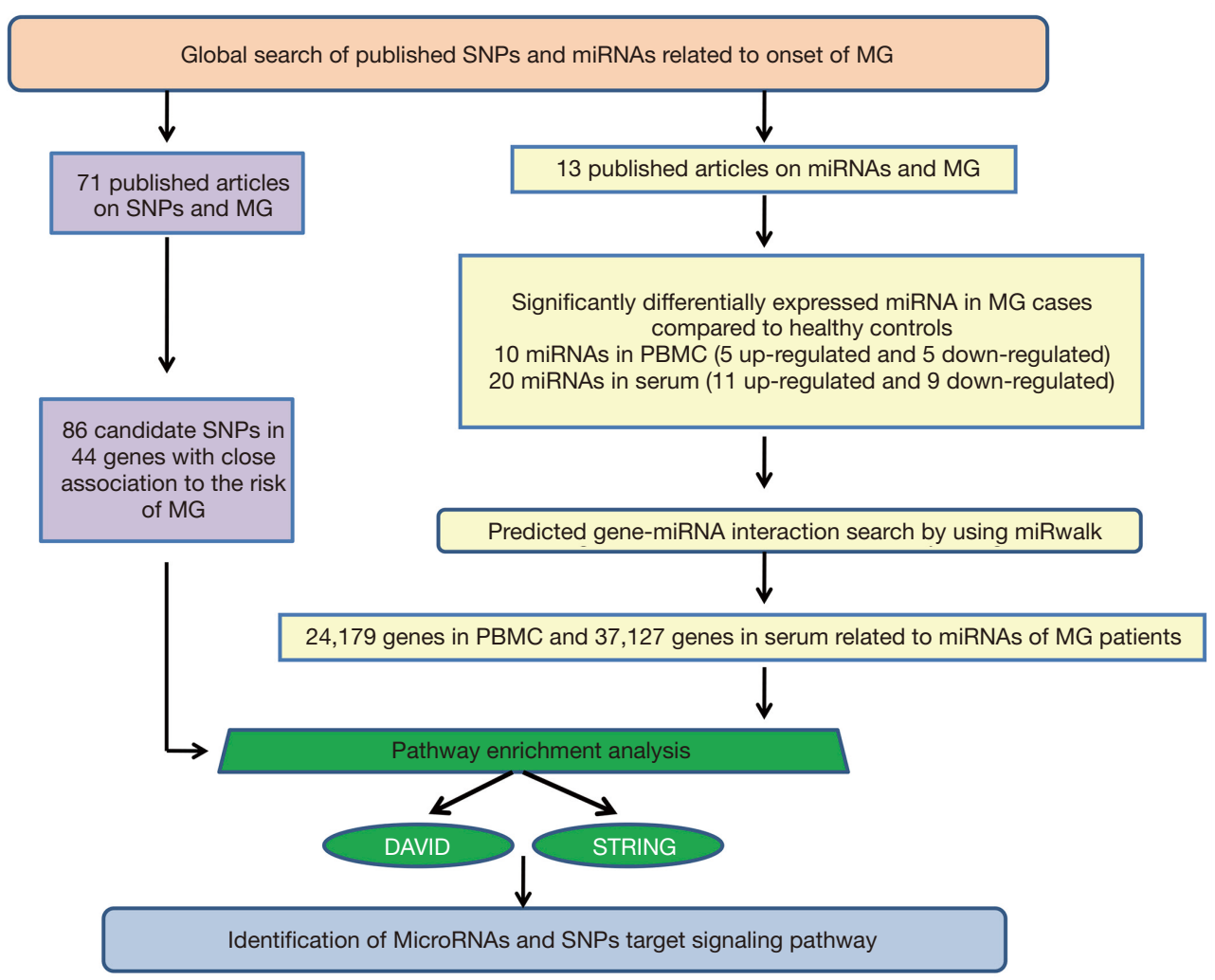

Figure 1 Flow chart of the strategy of the global search in PUBMED, target-gene prediction, KEGG pathway enrichment and proteinprotein interaction (PPI) analysis.

\section{Statistical analysis}

Statistical analysis was carried out by using the MedCalc Statistical Software version v19.0.3 (MedCalc Software bvba, Ostend, Belgium). The key genes were defined as those with higher degrees of connectivity in PPIs, which were identified by a network topology analysis. The PathExNet tool was also used to isolate the genes that participate in each of the selected pathways based on KEGG 2019 along with the $\log \mathrm{FC}$ and $\mathrm{P}$ value metrics, as provided by the differential expression analysis (13).

\section{Results}

We identified 86 candidate SNPs located in 44 related genes from 71 articles (Table S2) and 30 miRNAs from 13 articles (Table S3).
Five genes containing the reported SNPs associated with $M G$ risk were involved in the inflammatory bowel disease (IBD) signaling patbway, and FoxP3 was the key gene

We used DAVID and STRING to identify signaling pathways of the 44 genes containing candidate SNPs (Table S1), and found these genes were involved in 15 signaling pathways (Table 1).

Cytoscape was utilized to construct the protein interaction network, which was used to calculate the score of gene nodes by using three centrality methods [i.e., Degree Centrality, Betweenness Centrality, and Closeness Centrality (9-11)]. Only one significant pathway was identified (gene counts $=5$, Bonferroni $\mathrm{P}$ value $<0.040$, and confidence scores $=0.59$ ), i.e., the IBD signaling pathway, involving five genes (Foxp3, IL6, IL10, IL1B, and TNF). Additionally, in these nodes with high degrees were 
Table 1 The genes containing candidate SNPs were involved in 15 signaling pathways

\begin{tabular}{|c|c|c|c|}
\hline Pathways & $P$ value & $P$ value FDR & $P$ value bonferroni \\
\hline 2. African trypanosomiasis & 8.18E-08 & $5.44 \mathrm{E}-03$ & $9.25 \mathrm{E}-02$ \\
\hline 3. Malaria & 3.23E-07 & 7.39E-03 & 1.33E-01 \\
\hline 4. Cytokine-cytokine receptor interaction & $7.40 \mathrm{E}-07$ & 8.26E-03 & $1.64 \mathrm{E}-01$ \\
\hline 6. Tuberculosis & 2.13E-06 & $1.11 \mathrm{E}-02$ & $2.40 \mathrm{E}-01$ \\
\hline 7. Rheumatoid arthritis & 3.87E-06 & $1.11 \mathrm{E}-02$ & $2.44 \mathrm{E}-01$ \\
\hline 8. Hematopoietic cell lineage & 3.87E-06 & 1.15E-02 & $2.73 \mathrm{E}-01$ \\
\hline 9. Chagas disease (American trypanosomiasis) & $6.29 \mathrm{E}-06$ & 1.15E-02 & $2.75 \mathrm{E}-01$ \\
\hline 12. Graft-versus-host disease & $1.27 \mathrm{E}-05$ & 1.26E-02 & $3.41 \mathrm{E}-01$ \\
\hline 13. Legionellosis & 4.09E-05 & $1.40 \mathrm{E}-02$ & 3.91E-01 \\
\hline 14. NOD-like receptor signaling pathway & 4.83E-05 & 1.41E-02 & $4.08 \mathrm{E}-01$ \\
\hline 15. Leishmaniasis & 9.03E-05 & $1.68 \mathrm{E}-02$ & $5.05 E-01$ \\
\hline
\end{tabular}

FDR, false discovery rate.

identified using a network topology analysis, FoxP3 was shown to be the key gene among them (Figure 2, Table 2). This result suggests that the inflammatory and immune may play an important role in the occurrence and development of MG.

\section{MiRNAs were involved in adberens junction, cancer- related and apoptosis patbways}

We identified 24,179 and 37,127 genes as potential targets of the significantly differentially-expressed miRNAs in $\mathrm{PBMC}$ and serum, respectively (https://cdn.amegroups.cn/ static/public/gs-20-39-01.docx).

In PBMC, 24,179 genes were found to be involved in 28 signaling pathways, but only one highly significant pathway, the adherens junction pathway $(\mathrm{FC}>0$ and $\mathrm{FC}<0)$, had a Bonferroni $\mathrm{P}$ value $<0.05$ (Table 3). In serum, 37,127 genes were involved in 36 signaling pathways, and cancer-related pathway $(\mathrm{FC}<0)$ and apoptosis pathways $(\mathrm{FC}>0)$ seemed to be the most significant pathways among them (Table 3).

The adherens junction pathway consists of 46 interactions involving 15 genes (Figure 3), key genes including mitogen-activated protein kinase 1 (MAPK1), SMAD family member 4 (SMAD4), and SMAD2 (Figure 3, Table 3).
In serum, the cancer-related pathway involved 67 genes and 379 interactions (Figure 4). However, it was too complicated to visualize these 379 interactions and identify the key genes, probably due to complicated variations and interactions of the genes involved in cancer biology. The apoptosis pathway involved 19 genes and 47 interactions (Figure 5). B-cell lymphoma 2 (BCL2) seemed to be the key gene among them (Figure 5).

\section{The key genes targeted by SNPs and miRNAs are involved in negative regulation of $T$ cell differentiation}

We used STRING to reveal the possible biological processes of five key genes i.e., BCL2, MAPK1, SMAD2, SMAD4 and Foxp3 targeted by miRNAs or SNPs. Intriguingly, we found these key genes seemed to be involved in a pathway which negatively regulates $\mathrm{T}$ cell differentiation (Figure 6).

\section{Discussion}

We analyzed the mutational gene using bioinformatics, and found that Foxp3 was involved as the key gene in the signaling pathway of IBD, which is a chronic, relapsing 


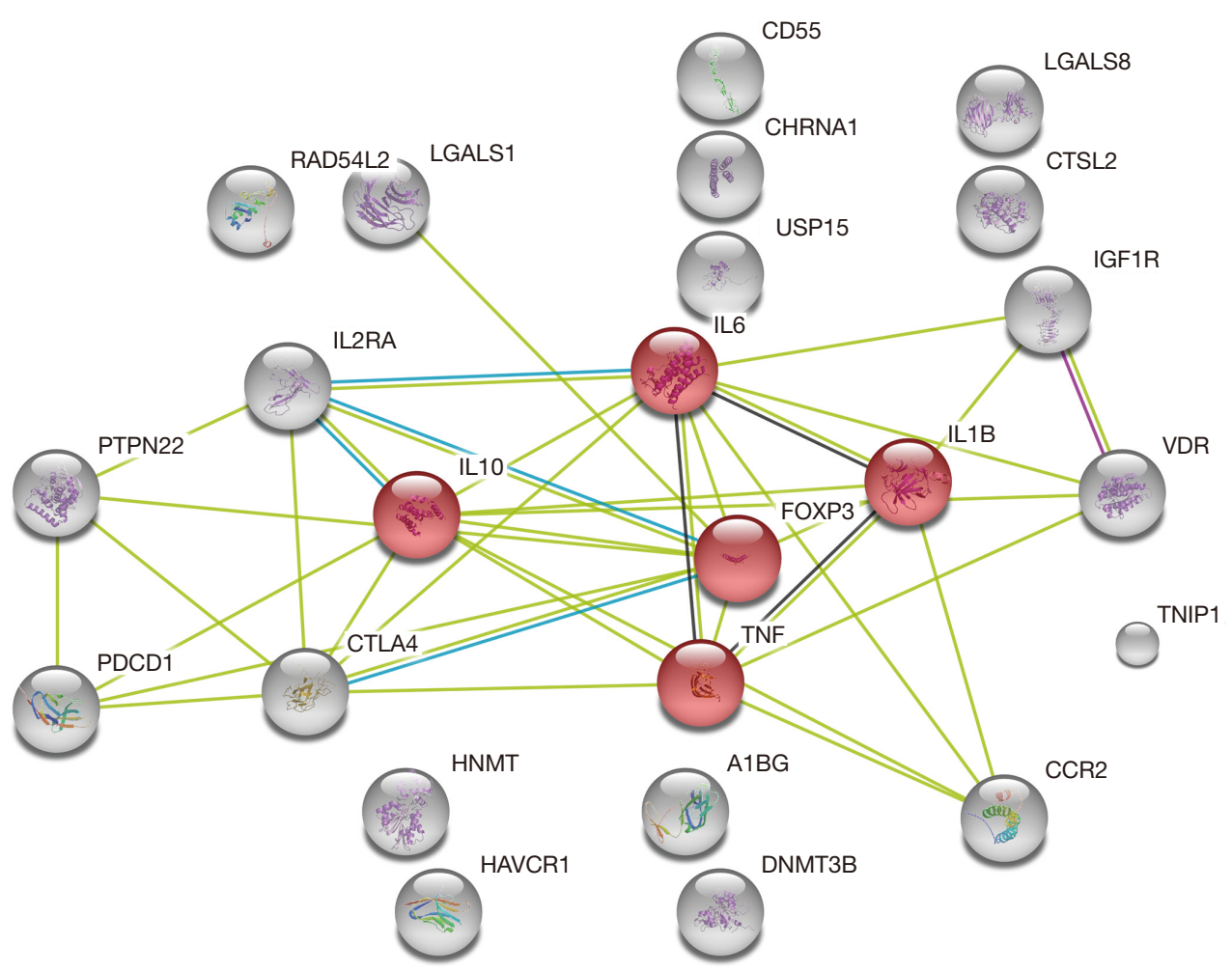

Figure 2 PPI analysis of 26 genes containing candidate SNPs related to high risk of MG. FoxP3 was shown to be the key gene. (Blue line: supported by database, yellow line: confirmed by experiment, red: closely-related genes, gray: unrelated genes).

Table 2 The degree centrality, betweenness centrality, and closeness centrality of the top five nodes in IBD signaling pathway

\begin{tabular}{lccc}
\hline Gene & Degree & Betweenness & Closeness \\
\hline Foxp3 & 13 & 3342.67 & 0.03264 \\
IL6 & 11 & 3015.60 & 0.03069 \\
IL1B & 11 & 2900.16 & 0.03089 \\
IL10 & 10 & 2917.63 & 0.03163 \\
TNF & 9 & 3011.86 & 0.03047 \\
\hline
\end{tabular}

Degree, results of degree centrality algorithm; betweenness, results of betweenness centrality algorithm; closeness, results of Closeness centrality algorithm.

inflammatory disorder and an autoimmune disease. Concomitantly, some of the gene mutations found in this study are also mutated in IBD, such as TIM3, IL-10, IL6 , and TNF $(14,15)$. Foxp3 regulates both the development and the function of CD4+CD25+ regulatory $\mathrm{T}$ cells (Tregs) (16). Tregs have been proven to control a variety of immune responses to maintain immune homeostasis, ranging from autoimmune diseases to inflammatory conditions (17).
In patients with $M G$, both the quantities and the functions of Tregs are significantly decreased, suggesting an important role of Tregs in the pathogenesis of MG (17). Tregs in MG patients show decreased expression of Foxp3 and IL-10 indicating a functional deficit. In patients with Foxp3 mutations, Tregs are absent or dysfunctional, always leading to severe autoimmune diseases, e.g., MG and IBD (18). Reduced Treg suppressive activity in MG patients is accompanied by elevated inflammatory cytokines 
Table 3 Pathway analysis results and pathway related genes (Bonferroni-corrected probability value <0.05)

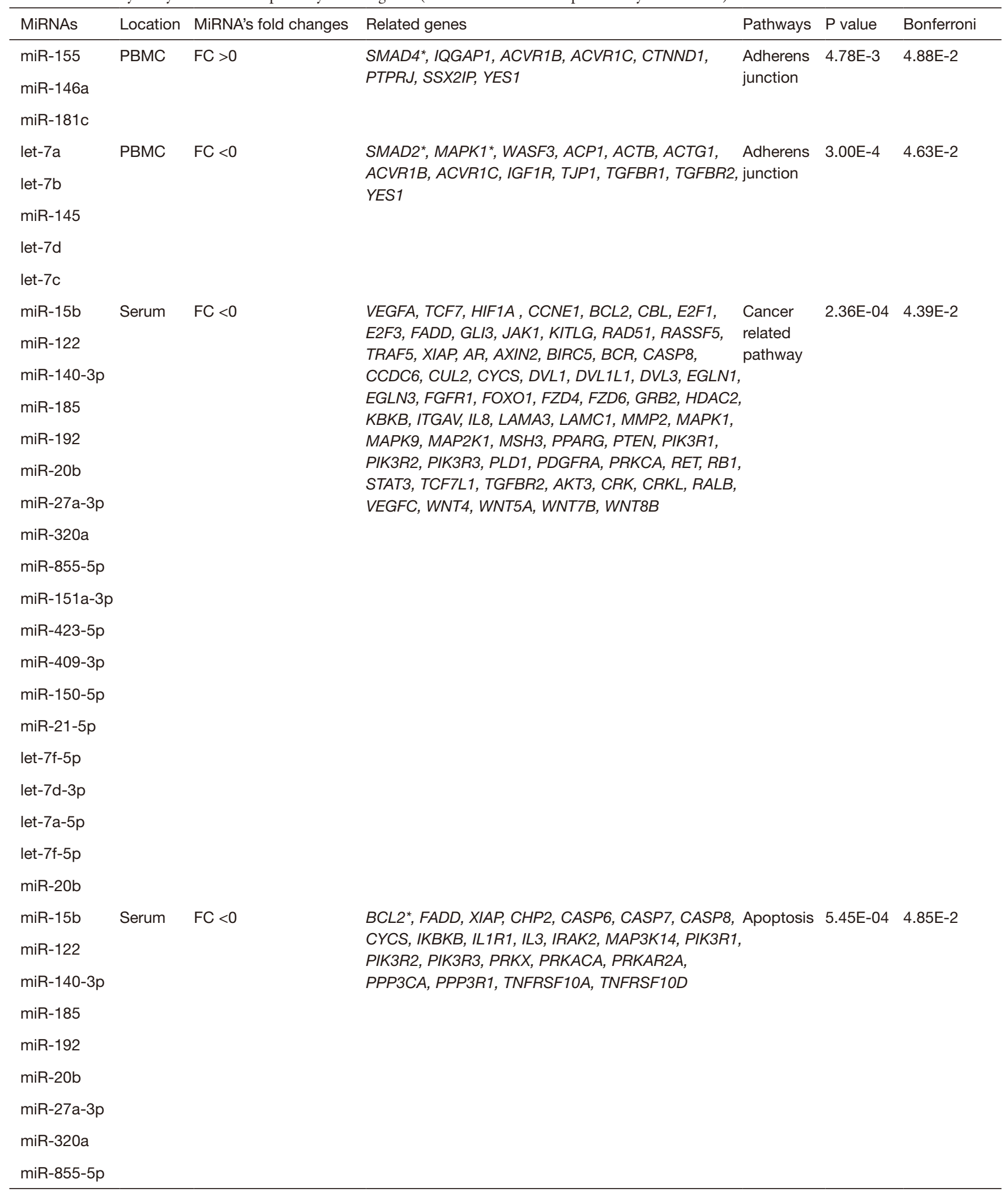

FC, Fold changes: expressions of miRNAs in PBMC or serum in between MG patient and normal control. *, leader genes. 


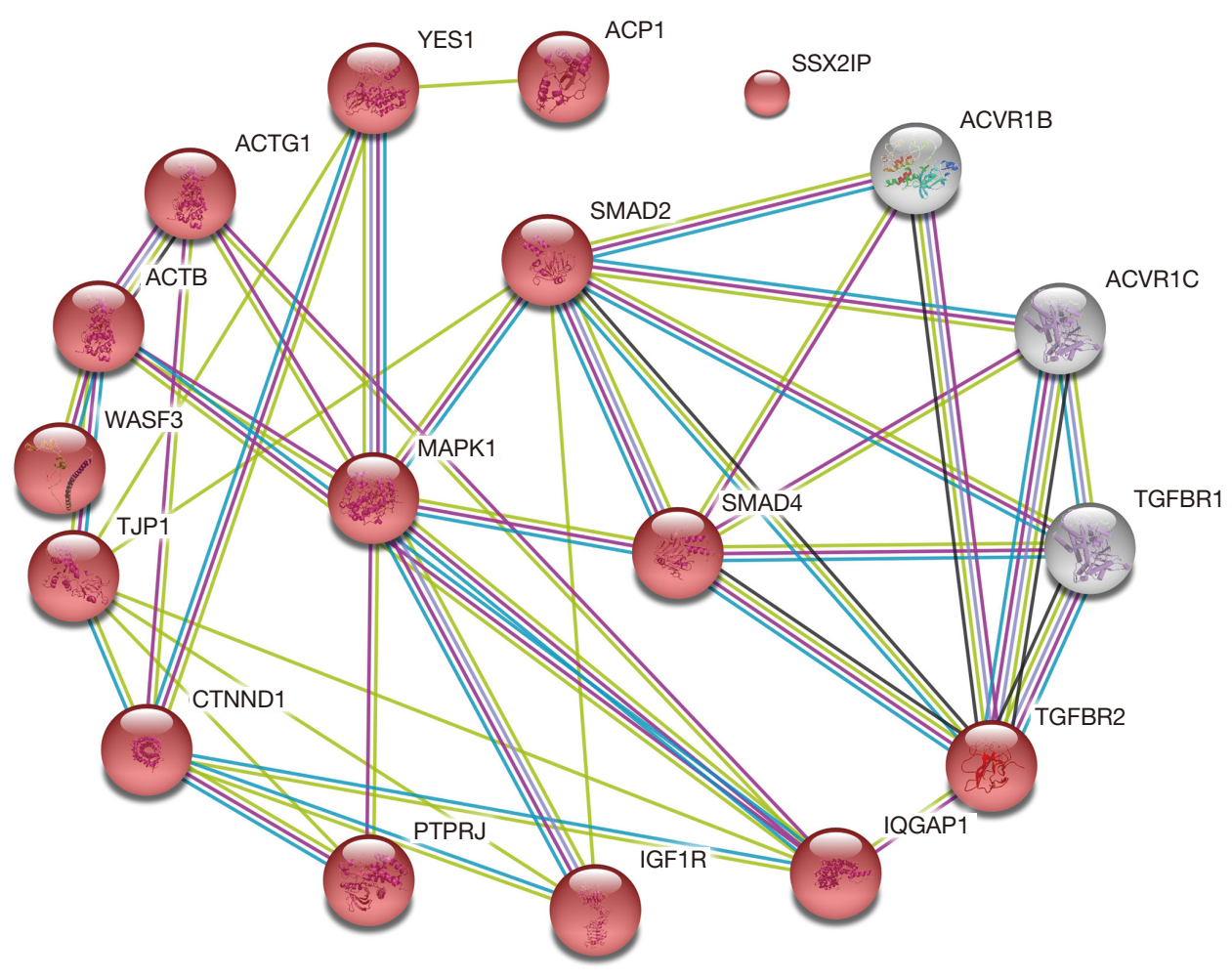

Figure 3 Genes targeted by the differentially-expressed miRNAs in PBMC of MG are involved in the adherens junction pathway (Blue line: supported by database, yellow line: confirmed by experiment, red: closely-related genes, gray: unrelated genes).

(IL-6, IL-17, TNF- $\alpha$, and IL-1 $\beta$ ), most of which are normally suppressed by Tregs (19). Immunomagneticallypurified Tregs from MG patients were found to suppress the proliferative response of other $\mathrm{T}$ cells (20). Leading to imbalance of T/B cells and subsequently affecting the production of auto antibodies $(21,22)$. Additionally, differentiation of Tregs is anticipated to be associated with myasthenia predisposition (23). Overall, the mechanisms of the IBD pathway in MG are unclear, but we speculate that at the DNA level, mutations of Foxp3 apply to Tregs, leading to severe autoimmune diseases via the IBD signaling pathway.

Recent study reveals that imbalance in $\mathrm{T}$ follicular helper cells (Tfh) producing IL-17 promotes proinflammatory responses in myasthenia gravis (24). The ratio of Tfh17/ Tfh1 has been shown to correlate with a pro-inflammatory and enhanced humoral immune response (25). Preite found that reconstitution of lymphopenic mice with CXCR5sufficient and CXCR5-deficient Treg cells, as well as nonregulatory memory $\mathrm{CD} 4 \mathrm{~T}$ cells, restrained expansion of Tfh and germinal center B cells, and restored germinal center B-cell dynamics and generation of highly mutated, high-affinity antibodies (26). In summary, in the occurrence and development of MG, Tregs control a variety of immune responses to maintain immune homeostasis, ranging from autoimmune diseases to inflammatory conditions (17).

The miRNAs play crucial roles in controlling and modulating immunity (27). Thus far, epidemiology studies have revealed miRNAs differentially expressed in patients with MG (Table S2); however, the target genes and related pathways remain unclear. We used bioinformatics tools to predict target genes and potential pathways of these miRNAs. Our study identified three critical pathways in the onset of MG, including one pathway in PBMC, the adherens junction signaling pathway, and two pathways in serum, the apoptosis and cancer-related pathways.

The adherens junction signal pathway is a key player in the establishment and maintenance of apical-basal cell polarity, regulation of cell proliferation, mobility, and differentiation (28). However, our study found that the differentially-expressed miRNAs in MG may be involved in the adherens junction pathway, in which MAPK1, (also 


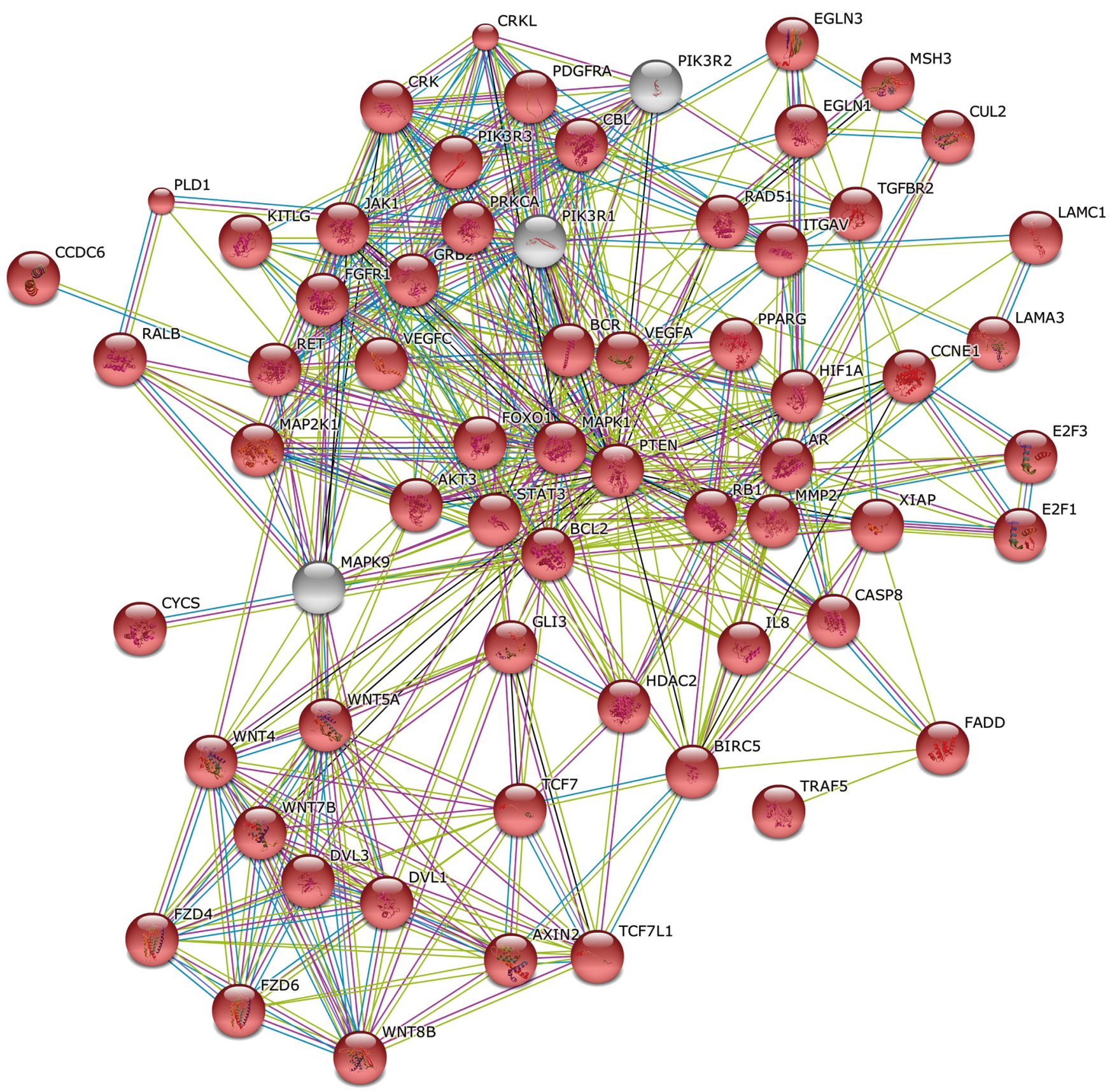

Figure 4 Genes targeted by the differentially-expressed miRNAs in serum were associated with cancer-related pathways (Blue line: supported by database, yellow line: confirmed by experiment, red: closely-related genes, gray: unrelated genes).

known as Erk2), SMAD 2 and 4 are the key genes. MAPK1 is essential to the signal transduction of extracellular stimuli from the membrane to the nucleus (29). Indeed, the amount of MAPK1 in MG serum was 11.5 times less than in controls (30). In addition, SMADs can activate intracellular
TGF- $\beta 1$ (31). Thereafter, the activated TGF- $\beta 1$ can induce the generation of CD4+Foxp3+ Tregs (32) and suppress proliferation of AChR-reactive T cells (32). Although the underlying mechanisms of MAPK1, SMAD2, and SMAD4 in the adherens junction pathway during the onset of MG 


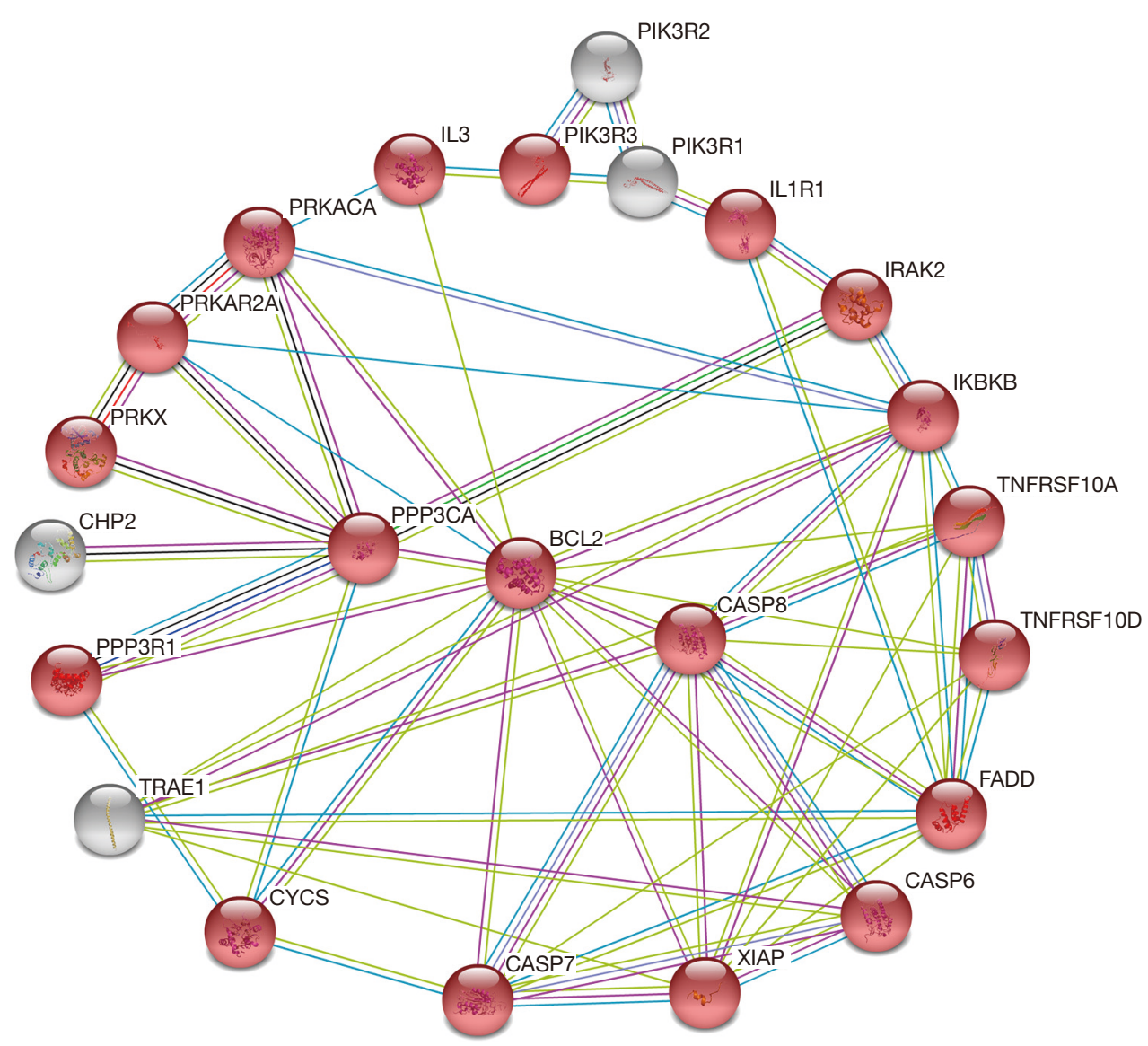

Figure 5 Genes targeted by the differentially-expressed miRNAs in serum showed a relationship with apoptosis (Blue line: supported by database, yellow line: confirmed by experiment, red: closely-related genes, gray: unrelated genes).

remain unclear, the relationship between this pathway and Tregs warrants further study.

Apoptosis plays an important role via Fas cascades in the onset of many other autoimmune diseases, as well as MG (33). The BCL2 gene located at chromosome 18q21, encodes a $26-\mathrm{kD}$ protein which is an apoptosis inhibitor (34). In thy0517 thymoma cells, BCL2 was found to be overexpressed (35). High expression of BCL2 may cause inhibition of apoptosis in thymocytes, and potentially induce the occurrence of thymoma (36). Although there is no evidence to prove the relationship between MG and BCL2, in another autoimmune disease, systemic lupus erythematosus (SLE), the expression of BCL2 may confer survival and proliferative advantages on Tregs and could represent a possible marker of SLE disease severity (37). Another study revealed that $\mathrm{T}$ cell-specific expression of a BCL2 mutant transgene results in enhanced rescue of thymocytes from negative selection, increasing development of Tregs (38). From these findings, we speculate that BCL2 plays an important role in apoptosis signaling through Tregs.

In summary, our study revealed that IBD, adherens junction, apoptosis, and cancer-related signaling pathways are probably involved in the pathogenesis of MG. Intriguingly, all the key genes targeted by SNPs or miRNAs, i.e., Foxp 3, SMAD2, MAPK1, SMAD4, and BCL2, seemed to be involved in negative regulation of $\mathrm{T}$ cell differentiation. Based on these findings, we hypothesized that SNPs cause the genes to be defective or the miRNAs to down regulate the factors that subsequently negatively regulate Tregs and trigger the onset of MG (Figure 6). Tregs are the core of MG pathogenesis. However, the studies analyzed describe the results from a diverse range of MG cases at different times after onset. The SNPs or miRNAs could also be the results of an immune response to an ongoing insult, immunosuppressive agent or thymus 


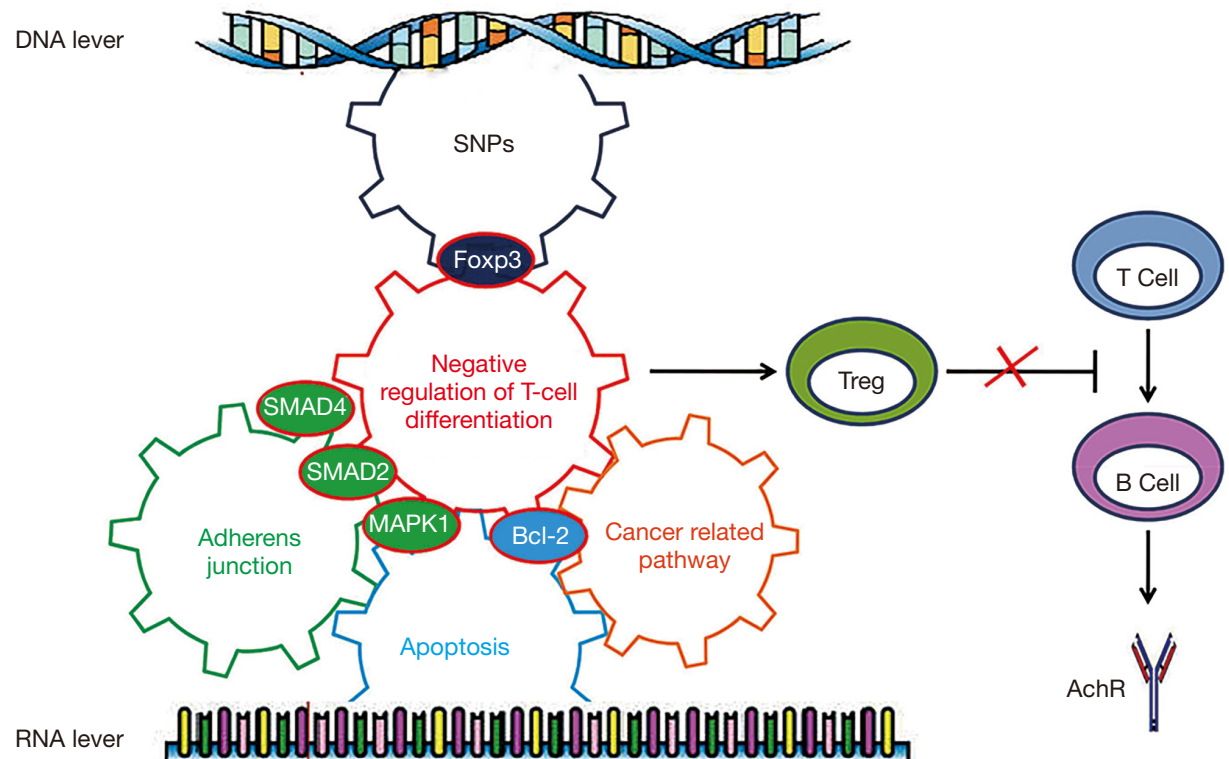

Figure 6 Five key genes Foxp3, MAPK1, SMAD2, SMAD4, and BCL2, are involved in negative regulation of T cell differentiation. We speculate that SNPs cause the genes to be defective or the miRNAs to down-regulate factors that subsequently negatively regulate Tregs and trigger the onset of MG.

pathology. Therefore, our hypothesis and the underlying mechanisms warrant further robust study.

\section{Acknowledgments}

Funding: This study is supported by the Technology Innovation and Application Development Project of Chongqing Province (cstc2019jscx-msxmX0233).

\section{Footnote}

Reporting Checklist: The authors have completed the MDAR reporting checklist. Available at http://dx. doi. org/10. 21037/gs-20-39

Conflicts of Interest: All authors have completed the ICMJE uniform disclosure form (available at http://dx. doi. org/10. 21037/gs-20-39). The authors have no conflicts of interest to declare.

Ethical Statement: The authors are accountable for all aspects of the work in ensuring that questions related to the accuracy or integrity of any part of the work are appropriately investigated and resolved. The study was conducted in accordance with the Declaration of Helsinki (as revised in 2013).

Open Access Statement: This is an Open Access article distributed in accordance with the Creative Commons Attribution-NonCommercial-NoDerivs 4.0 International License (CC BY-NC-ND 4.0), which permits the noncommercial replication and distribution of the article with the strict proviso that no changes or edits are made and the original work is properly cited (including links to both the formal publication through the relevant DOI and the license). See: https://creativecommons.org/licenses/by-nc-nd/4.0/.

\section{References}

1. Muñiz-Castrillo S, Joubert B, Elsensohn MH, et al. AntiCASPR2 clinical phenotypes correlate with HLA and immunological features. J Neurol Neurosurg Psychiatry 2020;91:1076-84.

2. Varade J, Wang N, Lim CK, et al. Novel genetic loci associated HLA-B*08:01 positive myasthenia gravis. J Autoimmun 2018;88:43-9.

3. Saruhan-Direskeneli G, Hughes T, Yilmaz V, et al. Genetic heterogeneity within the HLA region in three distinct clinical subgroups of myasthenia gravis. Clin Immunol 2016;166-167:81-8. 
4. Cavalcante P, Mizrachi T, Barzago C, et al. MicroRNA signature associated with treatment response in myasthenia gravis: A further step towards precision medicine. Pharmacol Res 2019;148:104388.

5. Cron MA, Maillard S, Delisle F, et al. Analysis of microRNA expression in the thymus of Myasthenia Gravis patients opens new research avenues. Autoimmun Rev 2018;17:588-600.

6. Sticht C, De La Torre C, Parveen A, et al. miRWalk: An online resource for prediction of microRNA binding sites. PLoS One 2018;13:e0206239.

7. DiChiacchio L, Sloma MF, Mathews DH. AccessFold: predicting RNA-RNA interactions with consideration for competing self-structure. Bioinformatics 2016;32:1033-9.

8. Holt J, McMillan L. Merging of multi-string BWTs with applications. Bioinformatics 2014;30:3524-31.

9. Cukierski WJ, Foran DJ. Using Betweenness Centrality to Identify Manifold Shortcuts. Proc IEEE Int Conf Data Min 2008;2008:949-58.

10. Du Y, Gao C, Chen X, et al. A new closeness centrality measure via effective distance in complex networks. Chaos 2015;25:033112.

11. Gao Y, Zhang S, Zhang Y, et al. Identification of MicroRNA-Target Gene-Transcription Factor Regulatory Networks in Colorectal Adenoma Using Microarray Expression Data. Front Genet 2020;11:463.

12. Beg MS, Brenner AJ, Sachdev J, et al. Phase I study of MRX34, a liposomal miR-34a mimic, administered twice weekly in patients with advanced solid tumors. Invest New Drugs 2017;35:180-8.

13. Kakouri AC, Votsi C, Tomazou M, et al. Analyzing Gene Expression Profiles from Ataxia and Spasticity Phenotypes to Reveal Spastic Ataxia Related Pathways. Int J Mol Sci 2020;21:E6722.

14. Li X, Chen G, Li Y, et al. Involvement of T cell Ig Mucin-3 (Tim-3) in the negative regulation of inflammatory bowel disease. Clin Immunol 2010;134:169-77.

15. Suzuki T, Sasahara Y, Kikuchi A, et al. Targeted Sequencing and Immunological Analysis Reveal the Involvement of Primary Immunodeficiency Genes in Pediatric IBD: a Japanese Multicenter Study. J Clin Immunol 2017;37:67-79.

16. De Obaldia ME, Bhandoola A. Transcriptional regulation of innate and adaptive lymphocyte lineages. Annu Rev Immunol 2015;33:607-42.

17. Zhang Y, Wang HB, Chi LJ, et al. The role of FoxP3+CD4+CD25hi Tregs in the pathogenesis of myasthenia gravis. Immunol Lett 2009;122:52-7.

18. van Herk EH, Te Velde AA. Treg subsets in inflammatory bowel disease and colorectal carcinoma: Characteristics, role, and therapeutic targets. J Gastroenterol Hepatol 2016;31:1393-404.

19. Thiruppathi M, Rowin J, Ganesh B, et al. Impaired regulatory function in circulating $\mathrm{CD} 4(+) \mathrm{CD} 25$ (high) CD127(low/-) $\mathrm{T}$ cells in patients with myasthenia gravis. Clin Immunol 2012;145:209-23.

20. Truffault F, Nazzal D, Verdier J, et al. Comparative Analysis of Thymic and Blood Treg in Myasthenia Gravis: Thymic Epithelial Cells Contribute to Thymic Immunoregulatory Defects. Front Immunol 2020;11:782.

21. Xu H, Zhang $\mathrm{M}, \mathrm{Li} \mathrm{XL}$, et al. Corrigendum to: "low and high doses of ursolic acid ameliorate experimental autoimmune myasthenia gravis through different pathways" [Journal of Neuroimmunology 281 (2015) 6167]. J Neuroimmunol 2019;330:181-3.

22. Niu L, Jiang J, Yin Y, et al. LncRNA XLOC_003810 modulates thymic Th17/Treg balance in myasthenia gravis with thymoma. Clin Exp Pharmacol Physiol 2020;47:989-96.

23. Chen Y, Li S, Huang R, et al. Comprehensive metaanalysis reveals an association of the HLA-DRB1*1602 allele with autoimmune diseases mediated predominantly by autoantibodies. Autoimmun Rev 2020;19:102532 .

24. Li Y, Guptill JT, Russo MA, et al. Imbalance in T follicular helper cells producing IL-17 promotes pro-inflammatory responses in MuSK antibody positive myasthenia gravis. J Neuroimmunol 2020;345:577279.

25. Locci M, Havenar-Daughton C, Landais E, et al. Human circulating PD-1+CXCR3-CXCR5+ memory Tfh cells are highly functional and correlate with broadly neutralizing HIV antibody responses. Immunity 2013;39:758-69.

26. Preite S, Baumjohann D, Foglierini M, et al. Somatic mutations and affinity maturation are impaired by excessive numbers of $T$ follicular helper cells and restored by Treg cells or memory T cells. Eur J Immunol 2015;45:3010-21.

27. Runtsch MC, Hu R, Alexander M, et al. MicroRNA-146a constrains multiple parameters of intestinal immunity and increases susceptibility to DSS colitis. Oncotarget 2015;6:28556-72.

28. Yang CC, Graves HK, Moya IM, et al. Differential regulation of the Hippo pathway by adherens junctions and apical-basal cell polarity modules. Proc Natl Acad Sci U S A 2015;112:1785-90.

29. Chen S, Evans HG, Evans DR. FAM129B/MINERVA, a novel adherens junction-associated protein, suppresses 
apoptosis in HeLa cells. J Biol Chem 2011;286:10201-9.

30. Cheng Z, Qiu S, Jiang L, et al. MiR-320a is downregulated in patients with myasthenia gravis and modulates inflammatory cytokines production by targeting mitogen-activated protein kinase 1. J Clin Immunol 2013;33:567-76.

31. Rizzo S, Basso C, Lazzarini E, et al. TGF-beta1 pathway activation and adherens junction molecular pattern in nonsyndromic mitral valve prolapse. Cardiovasc Pathol 2015;24:359-67.

32. Chae CS, Kwon HK, Hwang JS, et al. Prophylactic effect of probiotics on the development of experimental autoimmune myasthenia gravis. PLoS One 2012; 7:e52119.

33. Mai W, Liu X, Fan Y, et al. Up-regulated expression of Fas antigen in peripheral $\mathrm{T}$ cell subsets in patients with myasthenia gravis. Clin Invest Med 2012;35:E294.

34. Hockenbery D, Nunez G, Milliman C, et al. Bcl-2 is

Cite this article as: Qian $\mathrm{K}, \mathrm{Xu} \mathrm{JX}$, Deng Y, Peng H, Peng J, Ou CM, Liu Z, Jiang LH, Tai YH. Signaling pathways of genetic variants and miRNAs in the pathogenesis of myasthenia gravis. Gland Surg 2020;9(6):1933-1944. doi: 10.21037/gs-20-39 an inner mitochondrial membrane protein that blocks programmed cell death. Nature 1990;348:334-6.

35. Wang G, Wang Y, Zhang P, et al. Establishment and characterization of a novel cell line derived from thymoma with myasthenia gravis patients. Thorac Cancer 2015;6:194-201.

36. Salakou S, Kardamakis D, Tsamandas AC, et al. Increased $\mathrm{Bax} / \mathrm{Bcl}-2$ ratio up-regulates caspase-3 and increases apoptosis in the thymus of patients with myasthenia gravis. In Vivo 2007;21:123-32.

37. Goropevšek A, Gorenjak M, Gradisnik S, et al. STAT5 phosphorylation in CD4 $\mathrm{T}$ cells from patients with SLE is related to changes in their subsets and follow-up disease severity. J Leukoc Biol 2017;101:1405-18.

38. Burger ML, Leung KK, Bennett MJ, et al. T cell-specific inhibition of multiple apoptotic pathways blocks negative selection and causes autoimmunity. Elife 2014;3:e03468. 
Table S1 The search strategies in PubMed

("Myasthenia Gravis"[Mesh] OR (((("myasthenia gravis"[MeSH Terms] OR ("myasthenia"[All Fields] AND "gravis"[All Fields]) OR "myasthenia gravis"[All Fields]) AND Ocular[Title/Abstract]) OR Ocular Myasthenia Gravis[Title/Abstract]) OR (("myasthenia gravis"[MeSH Terms] OR ("myasthenia"[All Fields] AND "gravis"[All Fields]) OR "myasthenia gravis"[All Fields]) AND Generalized[Title/Abstract])) OR Generalized Myasthenia Gravis[Title/Abstract])) AND $((()((()(()(((($ MicroRNA[Title/Abstract] OR miRNAs[Title/Abstract]) OR Micro RNA[Title/ Abstract]) OR (("rna"[MeSH Terms] OR "rna"[All Fields]) AND Micro[Title/Abstract])) OR miRNA[Title/Abstract]) OR Primary MicroRNA[Title/ Abstract]) OR (("micrornas"[MeSH Terms] OR "micrornas"[All Fields] OR "microrna"[All Fields]) AND Primary[Title/Abstract])) OR Primary miRNA[Title/Abstract]) OR (("micrornas"[MeSH Terms] OR "micrornas"[All Fields] OR "mirna"[All Fields]) AND Primary[Title/Abstract])) OR pri-miRNA[Title/Abstract]) OR pri miRNA[Title/Abstract]) OR (("rna"[MeSH Terms] OR "rna"[All Fields]) AND Small Temporal[Title/Abstract])) OR (Temporal[All Fields] AND ("rna"[MeSH Terms] OR "rna"[All Fields]) AND Small[Title/Abstract])) OR stRNA[Title/Abstract]) OR Small Temporal RNA[Title/Abstract]) OR pre-miRNA[Title/Abstract]) OR pre miRNA[Title/Abstract]) AND "MicroRNAs"[Mesh])

(((("Myasthenia Gravis"[Mesh]) OR ((((Myasthenia Gravis, Ocular[Title/Abstract]) OR Ocular Myasthenia Gravis[Title/Abstract]) OR Myasthenia Gravis, Generalized[Title/Abstract]) OR Generalized Myasthenia Gravis[Title/Abstract]))) AND (("Polymorphism, Genetic"[Mesh]) OR ((((Polymorphisms, Genetic[Title/Abstract]) OR Genetic Polymorphism[Title/Abstract]) OR Polymorphism (Genetics)[Title/Abstract]) OR Genetic Polymorphisms[Title/Abstract])))

(((("Myasthenia Gravis"[Mesh]) OR ((((Myasthenia Gravis, Ocular[Title/Abstract]) OR Ocular Myasthenia Gravis[Title/Abstract]) OR Myasthenia Gravis, Generalized[Title/Abstract]) OR Generalized Myasthenia Gravis[Title/Abstract]))) AND (("Polymorphism, Single Nucleotide"[Mesh]) OR (((((Nucleotide Polymorphism, Single[Title/Abstract]) OR Nucleotide Polymorphisms, Single[Title/Abstract]) OR Polymorphisms, Single Nucleotide[Title/Abstract]) OR Single Nucleotide Polymorphisms[Title/Abstract]) OR SNPs[Title/Abstract]) OR Single Nucleotide Polymorphism[Title/Abstract])))

(((("Myasthenia Gravis"[Mesh]) OR ((((Myasthenia Gravis, Ocular[Title/Abstract]) OR Ocular Myasthenia Gravis[Title/Abstract]) OR Myasthenia Gravis, Generalized[Title/Abstract]) OR Generalized Myasthenia Gravis[Title/Abstract]))) AND (("Genome-Wide Association Study" [Mesh]) OR ((()((()(((((Association Studies, Genome-Wide[Title/Abstract]) OR Association Study, Genome-Wide[Title/Abstract]) OR Genome-Wide Association Studies[Title/Abstract]) OR Studies, Genome-Wide Association[Title/Abstract]) OR Study, Genome-Wide Association[Title/Abstract]) OR Genome Wide Association Scan[Title/Abstract]) OR Genome Wide Association Studies[Title/Abstract]) OR GWA Study[Title/Abstract]) OR GWA Studies[Title/Abstract]) OR Studies, GWA[Title/Abstract]) OR Study, GWA[Title/Abstract]) OR Whole Genome Association Analysis[Title/Abstract]) OR Whole Genome Association Study[Title/Abstract]) OR Genome Wide Association Analysis[Title/Abstract]) OR Genome Wide Association Study[Title/Abstract]))) 


\begin{tabular}{|c|c|c|c|c|c|c|c|}
\hline PMD & Authors & Gene & Genotype & Ethnic group or dessent & Cases & Heathy controls & Odds ratio $995 \%$ CI) or other results \\
\hline 283642966 & 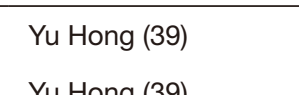 & ARE & 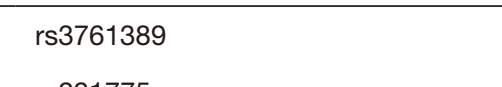 & Chinese & 114 Adult MG (18-40 years) & 487 & 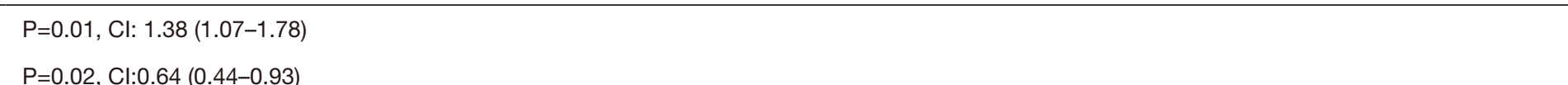 \\
\hline $\begin{array}{l}28303424296 \\
28360\end{array}$ & $\begin{array}{l}\text { Yrunorg( (39) } \\
\text { Yu Hong (39) }\end{array}$ & $\begin{array}{l}\text { CTLLA- } \\
\text { CTLA-4 }\end{array}$ & 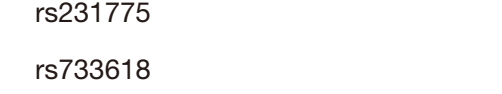 & $\begin{array}{l}\text { Chines } \\
\text { Chinse }\end{array}$ & 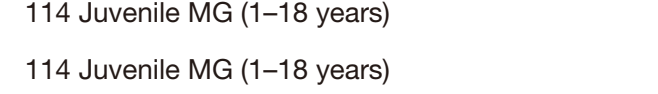 & $\begin{array}{l}{ }_{487}^{487} \\
\end{array}$ & 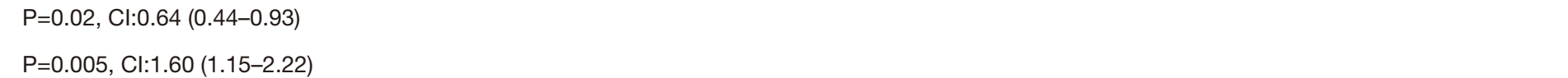 \\
\hline 28364296 & Yu Hong (39) & CHANAT & rst86628477 & Chinese & 114 Juvenile MG (1-18 y years) & 487 & $P=0.03,(12.204(1.06-3.390)$ \\
\hline $\begin{array}{l}288642969 \\
28362969\end{array}$ & Yu Hong (39) & CHANAT & ${ }^{152229957}$ & Chinsese & 114 Juvenile MG (1-18 years) & ${ }_{487}$ & $\mathrm{P}=0.0005, \mathrm{Cl} 2.264(1.50-4.43)$ \\
\hline $\begin{array}{l}28366296967 \\
1000977\end{array}$ & 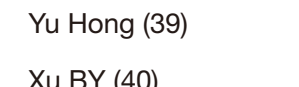 & CHANAT & ${ }^{15168628487}$ & Chinese & 207 Adut MG (18-40 years) & 487 & $\mathrm{P}=0.000, \mathrm{Cl}: 2.03(1.21-3.41)$ \\
\hline $\begin{array}{l}10006977 \\
10006977\end{array}$ & 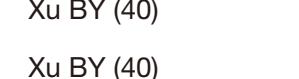 & $\begin{array}{l}A D B B 22 \\
A D B B 2\end{array}$ & $\begin{array}{l}\text { Arglarg } \\
\text { GivG }\end{array}$ & $\begin{array}{l}\text { Swedish } \\
\text { Swwedish }\end{array}$ & 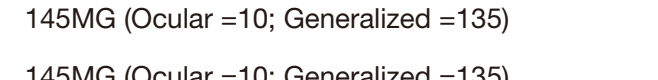 & & $P=0.0022 \quad O R=3.60(1.52-8.54)$ \\
\hline & $X \cup B Y(40)$ & ADRBS & $\begin{array}{l}\text { lilyly } \\
\text { Cariage of Gly }\end{array}$ & $\begin{array}{l}\text { Swearsh } \\
\text { Swwedish }\end{array}$ & 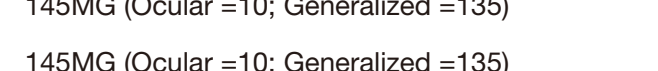 & $96 \mathrm{HC}$ & $P=0.0079$ OR=0.45 (0.26-0.81) \\
\hline 27338803 & Wang L (41) & ADRB2 & 年 & swealsh & 27 MG & $-56 \mathrm{CO}$ & $\begin{array}{l}\begin{array}{l}P=0.00220 \mathrm{OA}=0.27(0.12-0.66) \\
P=0.041\end{array}\end{array}$ \\
\hline 13552699 & $\begin{array}{l}\text { Degil:Esposti MA } \\
(42)\end{array}$ & BAT1 & 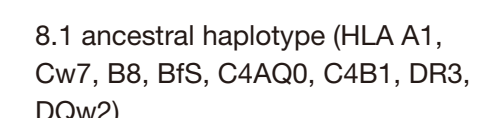 & Caucasooid & $16 \mathrm{MG}$ & $\begin{array}{l}16 \text { acut Caucasoid subijects } \\
\text { from Bussenton }\end{array}$ & $\mathrm{RR}=5.5$ \\
\hline 19513280 & Kim HS (43) & CCA2 & rst1798664 & Koraan & 109MG & 115 & $P<0.05$ \\
\hline 11857062 & Wang XB (44) & CTLAA & $+49 A G$ & Sweden & 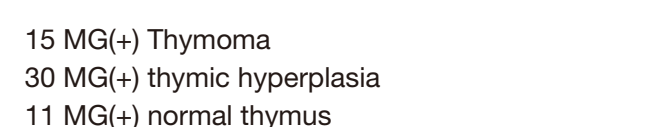 & 122 & $\begin{array}{l}\text { Thymoma vs. normal } \\
\text { and hyperplastic thymic: 8.44 (1.77-40.4) }\end{array}$ \\
\hline 16178018 & Chuang Wr (45) & CTLAA & $+49 \mathrm{NG}$ & German & $79 \mathrm{MG}(\mathrm{t})$ thymoma & $46 \mathrm{MG}(-)$ thymoma & 129 non-thymoma EOMG \\
\hline 18088253 & Wang $\times \mathrm{B}(46)$ & CTLA4 & $-1772 T / C-1661 A / G$ & Sweden & & 148 & $\begin{array}{l}1.87(1.01-3.49) \\
\end{array}$ \\
\hline 243735006 & Chuang Wr (47) & CTLA4 & & Caucasian & 116 LOMG patients & 172 & $P=0.0029,27(1,7-7.0)$ \\
\hline 19345707 & $\begin{array}{l}\text { Fefrnandez-Mestre } \\
\text { M (48) }\end{array}$ & CTLAA & ${ }^{49} A G$ & Venezuelans & 46 MG & $98 \mathrm{HC}$ & $P>0.05$ \\
\hline 18595775 & Gu (49) & CTLA-4 & 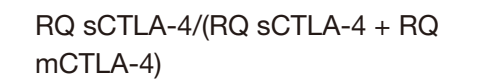 & Swedish Caucasian & $52 \mathrm{MG}$ patients & 31heathy individuals & $P_{<0.05}$ \\
\hline 12225005 & Wang XB (50) & CTLA-A & $\begin{array}{l}\text { (ATnn nolymmorphiss in } \\
\text { the }\end{array}$ & Swedish Caucasian & 96 AChR(t) MG patients & $\begin{array}{l}100 \text { etthically matched } \\
\text { hepthy }\end{array}$ & $\mathrm{p}<0.0001 ; \mathrm{r}=0.396$, \\
\hline 25643325 & Renton AE (51) & CTLA4 & rs231770 & $\begin{array}{l}\text { Whiti individuals from Nort } \\
\text { Americis thala cases }\end{array}$ & 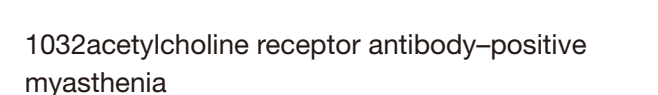 & 1998 heathy individuals & $1.37 ; 95 \% \mathrm{Cl}, 1.25-1.49$ \\
\hline 25643325 & Renton (51) & TNFRSF11A & ${ }^{544263037}$ & white individuals from Nortt & $\begin{array}{l}\text { gravis } \\
\text { the late-nsest cases in } 1032 \text { acetycholine }\end{array}$ & 1998 heatthy individuals & $1.44 ; 95 \%$ Cl, 1.29-1.53 \\
\hline 25003519 & $\operatorname{sun}\llcorner(52)$ & CTLA4 & 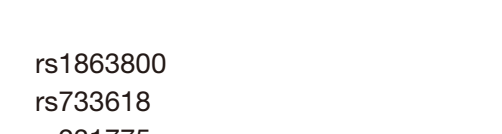 & $\begin{array}{l}\text { Amercica } \\
\text { Chinese }\end{array}$ & $\begin{array}{l}\text { recoptor antibody-positive myasthenia gravis } \\
168 \text { patients with MG }\end{array}$ & 233 heathy controls & 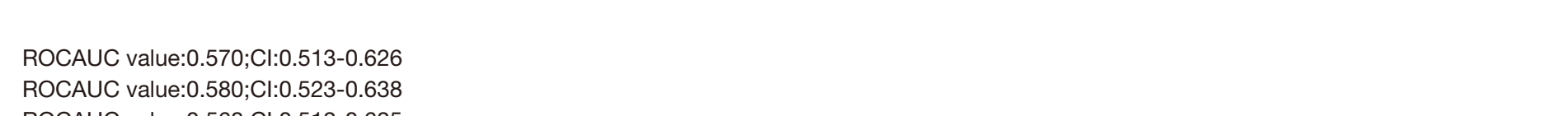 \\
\hline 11426323 & Ligers A (53) & CTLAA & $-3180 / 1 / 6$ & Sweden & г9 ма & ${ }_{26} 6 \mathrm{HC}$ & 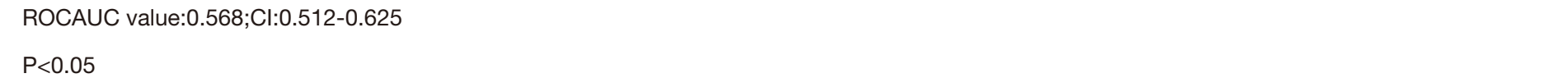 \\
\hline 11574100 & Franciota 0 (54) & CAA & CAAQOO & talalan & $81 \mathrm{MG}$ & $100 \mathrm{HC}$ & 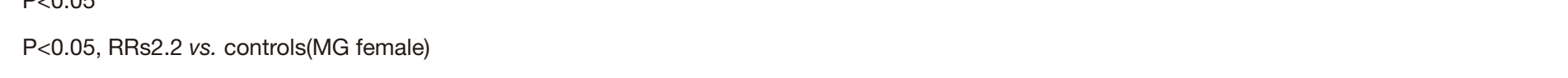 \\
\hline 11574100 & Franciota $D(54)$ & HLA & DRB 103 & talaian & $81 \mathrm{MG}$ & $100 \mathrm{HC}$ & 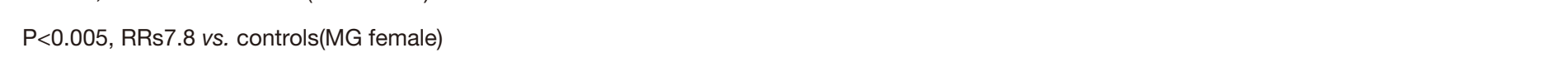 \\
\hline 11574100 & Franciotad D (54) & TNFB & TNEB 1 & talaian & 81 MG & $100 \mathrm{HC}$ & $P<0.05$, RBs. 0vs. controls (MG temale) \\
\hline 209429939 & $\begin{array}{l}\text { Ramanuiam } R \text { ( (55) } \\
\text { Garchon } H \text { (50) }\end{array}$ & CIITA & 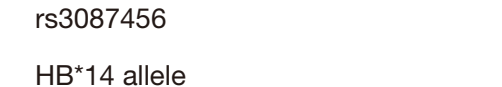 & $\begin{array}{l}\text { Swedish } \\
\text { Cacacasan }\end{array}$ & 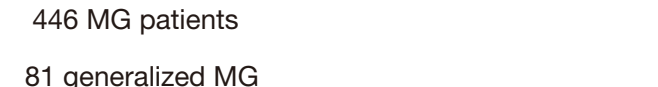 & $1866 \mathrm{HC}$ & $P=0.092 ; 0.86(0.73-1.02)$ \\
\hline 17687331 & $\begin{array}{l}\text { Garchon } \mathrm{H}(156) \\
\text { Giritud } M(57)\end{array}$ & $\begin{array}{l}\text { CHNAA } \\
\text { CHANAT }\end{array}$ & 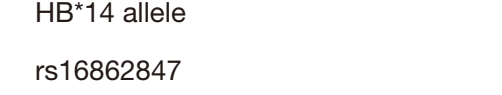 & $\begin{array}{l}\text { Caucasian } \\
\text { French United kingdom }\end{array}$ & 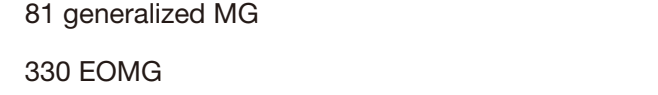 & $\begin{array}{l}10 \mathrm{MG} \\
260\end{array}$ & $\begin{array}{l}\text { P0.00002 } \\
\text { EoMG: 2.19(1.41-3.39) }\end{array}$ \\
\hline 14735155 & Giraud $M(58)$ & CHAND & 268 allele & French & $350 \mathrm{MG}$ & 168 & 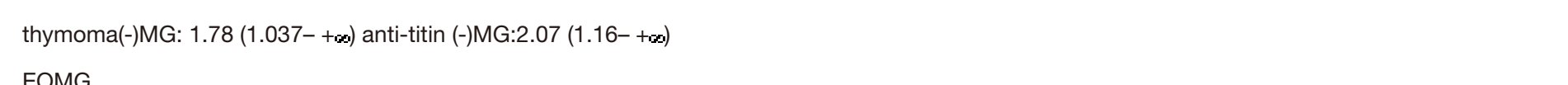 \\
\hline 17/8696649 & Viken MK (59) & & ${ }^{1543661859}$ & German & $\begin{array}{l}\text { 83 MG a apients } \\
\text { 31 EoMG }\end{array}$ & $244 \mathrm{HC}$ & $\begin{array}{l}\text { EOMG } \\
\text { OR }=1.82,95 \% \text { Cl: } 1.07-3-12, P=0.03\end{array}$ \\
\hline $\begin{array}{l}19675582 \\
2274667\end{array}$ & $\begin{array}{l}\text { JM Heckmann (60) } \\
\text { Landouré G(61) }\end{array}$ & $\begin{array}{l}\text { DAF } \\
\text { ENOX1 }\end{array}$ & $\begin{array}{l}\text { rs283771586 } \\
\text { D135219 - D13S326 }\end{array}$ & African & $\begin{array}{l}139 \text { EOP } \\
\text { Seven family members } 4 \text { MG, } 2 \text { unatfected, and }\end{array}$ & $\begin{array}{l}167 \\
764\end{array}$ & $\begin{array}{l}8.6(2.8-26.1) \\
P<0.001\end{array}$ \\
\hline 14597109 & van der Pol WL (62) & FCGR2A & Forilla-R/R131 & Dutch & 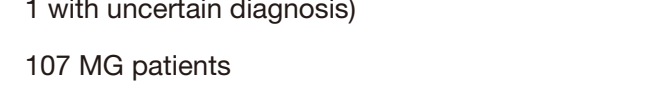 & ${ }_{239}^{23 \mathrm{HC}}$ & $P<0.017: 24,95 \%$ C11.43.3.9 \\
\hline 9521619 & Raknes $\mathrm{G}(63)$ & FGGR2A & Fogrill-H/H & Norwegia & & $49 \mathrm{HC}$ & \\
\hline $\begin{array}{l}23228687 \\
19693092\end{array}$ & $\begin{array}{l}\text { Zhang JM (64) } \\
\text { Chhang Wr (65) }\end{array}$ & $\begin{array}{l}\text { FoXP3 } \\
\text { PTRN22 }\end{array}$ & 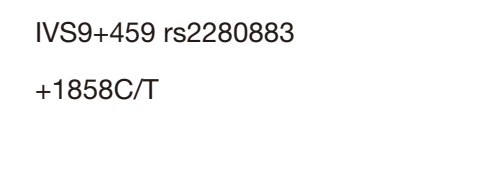 & $\begin{array}{l}\text { Chinese } \\
\text { German }\end{array}$ & 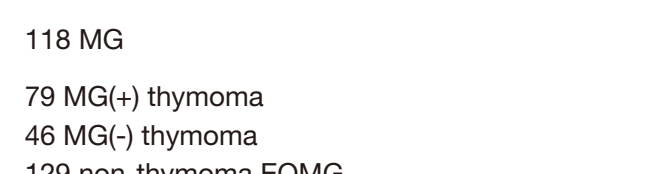 & $\begin{array}{l}124 \\
172\end{array}$ & $\begin{array}{l}\text { MGG(t): 0.44 (0.25-0.79) } \\
\text { MGG) thmmama. 2.66(1.38-5.12) } \\
\text { EOMG: } 2.81(1.58-5.00)\end{array}$ \\
\hline 194066179 & Greve B (66) & PTPN22 & $+1658 \mathrm{C} / \mathrm{T}$ & German Hungary & 50 anti-titin (t) non-thymoma MG & 379 & anti-titin (t) non-thymoma MG: 2.10 (1.23-3.5.58) \\
\hline 18533277 & Leveren (67) & PTPN22 & W620 variant & & 4о9ма & 1557 & $1.52(1.21-1.90)$ \\
\hline 25119822 & Gizem A.Kaya (68) & PTPN22 & rs24766001 & Turkey & 231AChR-MG & 293 & $2.5(1.2-5.5 .1)$ \\
\hline 166437561 & Vandiedonck C (69) & PTPN22 & ${ }^{1524766001}$ & French & 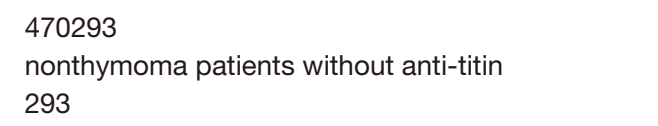 & 296 & thymoma(-)-2anti-titin(-1).97(1.32-2.97) \\
\hline & & & & & $\begin{array}{l}\text { nonthymmam patients without anti-titin } \\
293\end{array}$ & & \\
\hline & & & & & $\begin{array}{l}\text { nonhihmoma pater } \\
\text { 293MMa }\end{array}$ & & \\
\hline $\begin{array}{l}22197427 \\
26318187\end{array}$ & 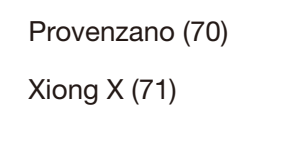 & $\begin{array}{l}\text { PTPN22 } \\
\text { PTPN22 F620W }\end{array}$ & $\begin{array}{l}{ }^{8242484457} \\
-\end{array}$ & 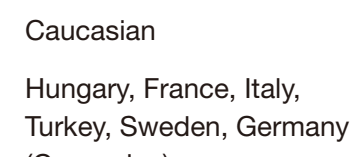 & 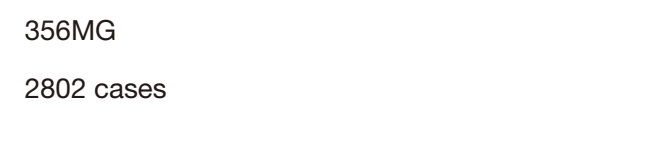 & $\begin{array}{l}439 \text { healthy individuals } \\
3730 \text { controls }\end{array}$ & 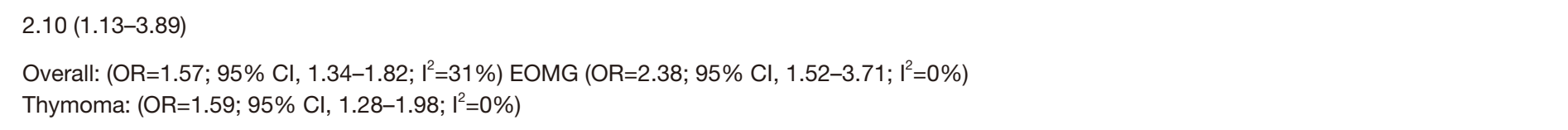 \\
\hline 23076337 & Zheng J (72) & PTRN22 & С1858т & & $1286 \mathrm{MG}$ & $2400 \mathrm{HC}$ & $\left.\mathrm{OR}=1.53 ; 95 \% \mathrm{Cl} 1.1 .31-1.80, \mathrm{P}=1.09 \times 10^{\top}\right)$ \\
\hline 23055271 & Gregersen PK (73) & PTPN22 & 152476601 & North European & 649 EOMG & $2596 \mathrm{HC}$ & $\mathrm{OR}=1.71, \mathrm{P}=8.2 \times 10^{-10} ; 95 \% \mathrm{Cl}: 1.44-2.02$ \\
\hline 23055271 & Gregersen PK (73) & TNIP1 & 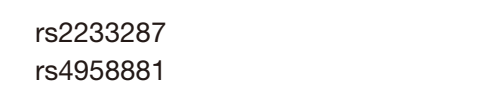 & North European & 649 EOMG & $2596 \mathrm{HC}$ & 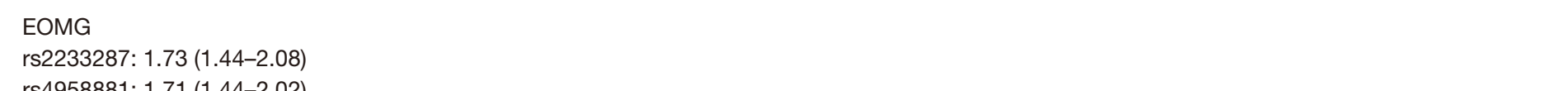 \\
\hline 23055271 & Gregersen PK (73) & HLA class I & rs7750641 & North European & 649 EOMG & $2596 \mathrm{HC}$ & $\mathrm{P}=1.2 \times 10^{-128,}, \mathrm{OR}=0.25(95 \%$ Cl: $4.89-6.85)$ \\
\hline 17509455 & YilmazV(74) & IFNG & $+874 \mathrm{~T}$ & Mixed & $\begin{array}{l}115 \text { pationts } \\
\text { AChB } \\
\text { ACA }(t)=92\end{array}$ & $200 \mathrm{HC}$ & 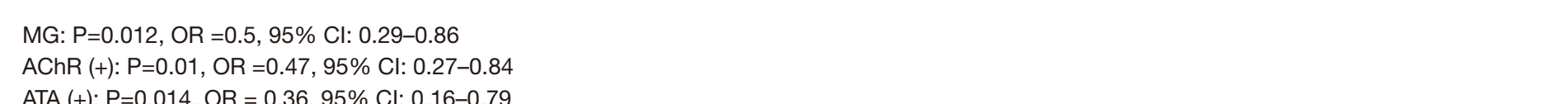 \\
\hline 17509455 & YilmazV $(74)$ & «10, & $-2763 \mathrm{~A}$ & Mixed & 115 patients & $200 \mathrm{HC}$ & 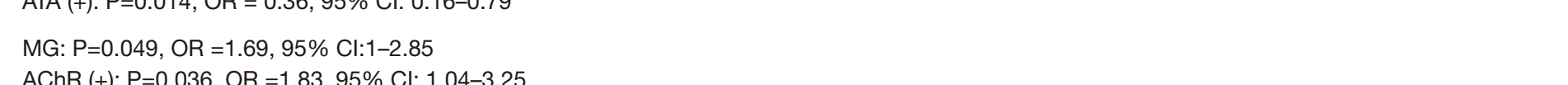 \\
\hline 25118158 & Lili Yang (75) & IGFIR & ${ }_{1528457573}$ & Chinese & 1вма & ${ }_{93}$ & 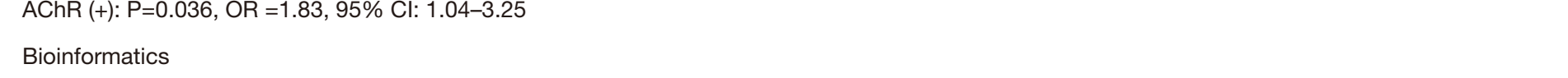 \\
\hline${ }_{22119518}$ & Palz (76) & $175 V(1 / 4$-4R) & rst1805010 & Caucasian & 214AChR(A)MG & 299 & $1.77(1.1-2.84)$ \\
\hline 11777547 & Sciacca $\mathrm{FL}(77)$ & LAA & & Italian & 421MG & 995 & associated with EOMG $(P=0.0044)$ in the whole $M G$ group \\
\hline 9521008 & Huang $D(78)$ & L1в & LL-1B Taq RFLP(A2/A2) & Swedish caucasian & 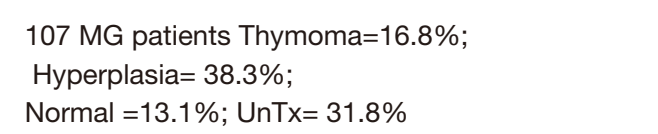 & 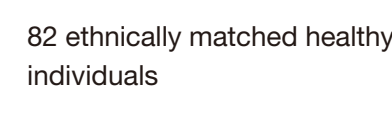 & The frequency of the genotype A2/A2 was significantly incere \\
\hline 10580002 & Huang D (79) & L6 & $-174 A \mathrm{ND}$ & Caucasian & 141MG & 127 & $\mathrm{OR}=17, \mathrm{p}<0.0001$ \\
\hline 10376939 & Huang DR (80) & 1110 & $134 \mathrm{G} / \mathrm{G}$ & Caucasian & $149 \mathrm{MG}$ & 109 & $\begin{array}{l}24 . \text { thymoma }(+1) \\
3.00(1.80-2.21)\end{array}$ \\
\hline 10376939 & Huang DR (80) & «10 & IL10.G, allele 134 & Swedish Caucasian & 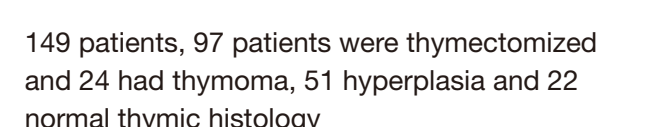 & $\begin{array}{l}109 \text { ethnicall matched } \\
\text { heathry invididuals }\end{array}$ & 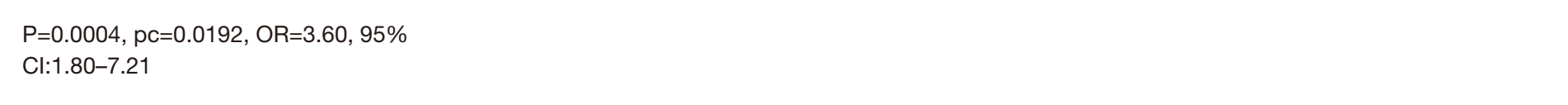 \\
\hline 23049601 & Zagoritiz Z(81) & $\mu-10$ & ACC/ACCACC/ATA & Greeks & $101 \mathrm{MG}$ & $101 \mathrm{HC}$ & $P=0.068$ \\
\hline 2030025 & 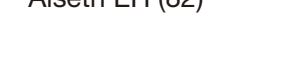 & $10+10$ & ACCIACC ACCIAAA & 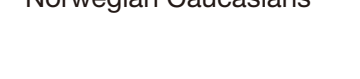 & 64 MG patentis & $87 \mathrm{HC}$ & 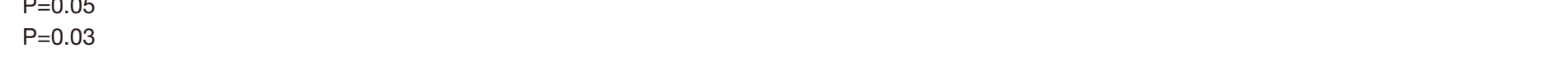 \\
\hline 26337/284 & Wue $x \times(38)$ & u-17 & 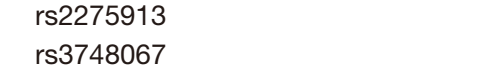 & Han Chinese population & $480 \mathrm{MG}$ patients & 487 controls & $P=0.428 ; C, 1,0.76(0.898-1.289)$ \\
\hline 200728477 & Palz(84) & LLALST & 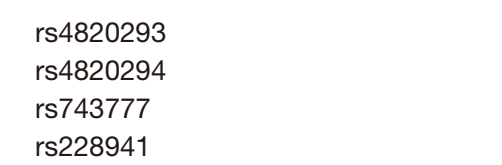 & Hungary & $146 \mathrm{MG}$ & 291 & $9.2(95 \%$ C I N.SP P $=0.021$ \\
\hline $\begin{array}{l}22683700 \\
23932992\end{array}$ & $\begin{array}{l}\text { PálZ (85) } \\
\text { Kellermayer B (86) }\end{array}$ & $\begin{array}{l}\text { LGALSB } \\
\text { HNMT }\end{array}$ & $\begin{array}{l}\mathrm{r} 22737713 \\
\text { A939G }\end{array}$ & $\begin{array}{l}\text { Caucasian } \\
\text { Caucasian }\end{array}$ & 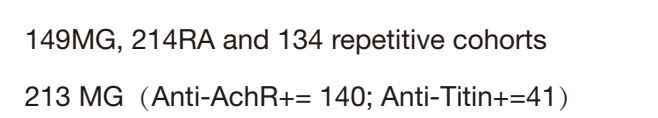 & $\begin{array}{l}365 \\
342 \mathrm{HC}\end{array}$ & 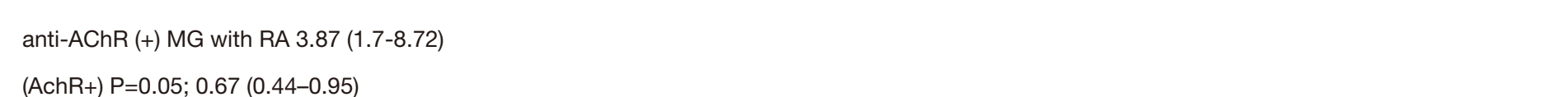 \\
\hline 22521184 & Naiba Fekin-Mrissa & HLA-DRB1 & 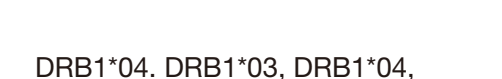 & Turisian patients & 48 MG patients $37.5 \%$, have thymomal & 100 heathy controls & 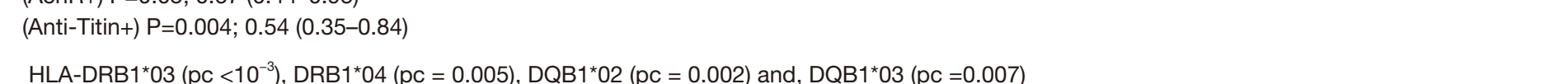 \\
\hline 22503410 & $\begin{array}{l}\text { (87) } \\
\text { ZhuWH (88) }\end{array}$ & $\begin{array}{l}\text { HLA-DDB1 } \\
\text { HLA-DDA1 }\end{array}$ & $\begin{array}{l}\text { DQB1*02, DQB1 } 1^{\circ 03} \\
\text { DQA }^{*} 03: 02\end{array}$ & Southern Han Chinese & $205 \mathrm{MG}$ patients & $100 \mathrm{HC}$ & 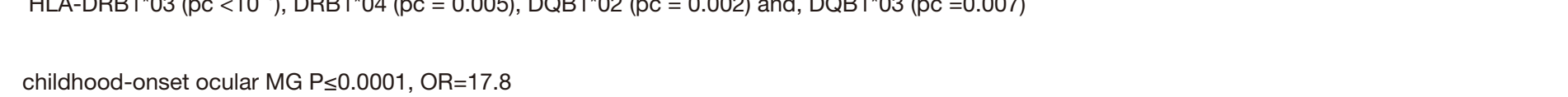 \\
\hline 21917268 & Vang & $\begin{array}{l}\text { FLAADEST } \\
\text { HLA-DDAT }\end{array}$ & DDAA'0103 & Northern Han Chinese & $84 \mathrm{MG}$ patients & $293 \mathrm{HC}$ & $\mathrm{P}=0.000,0 \mathrm{OP}: 0.24,95 \% \mathrm{Cl}: 0.13-0.49$ \\
\hline 23091703 & Testi M90) & $\begin{array}{l}\text { HALLDOBI } \\
\text { HLDADB }\end{array}$ & DQB ${ }^{* 05} 502$ & Italaia pationts & 28 (absence of thymmoma, the presence of $A C h R$ & 100 heathly controls & 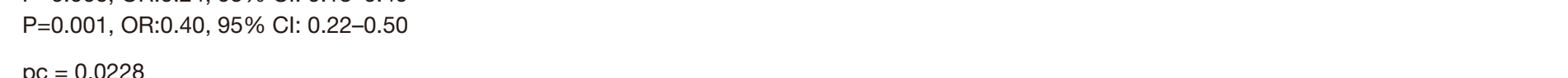 \\
\hline 19400212 & Hajerer $A$ H (91) & HLA-A & HLA-BOOS & Saudi & $\begin{array}{l}\text { and LOMG) } \\
109 \mathrm{MG}\end{array}$ & з883 $\mathrm{HC}$ & OR:25:95\% Cl: 1.64-3.38: P=0.00001 \\
\hline 19561379 & Yousefipour $6 A$ (92) & & & & & & \\
\hline & & 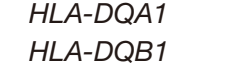 & $\begin{array}{l}\text { DAA1+0101/2 } \\
\text { DQB1 } 05022\end{array}$ & sporadici patients & 104MG & 816 heathy controls & $\begin{array}{c}\mathrm{pc}=1.69 \\
\mathrm{pc}=2.41\end{array}$ \\
\hline 16720217 & 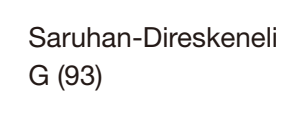 & $\begin{array}{l}\text { HLA-DDAT } \\
\text { HLADODB1 }\end{array}$ & $\mathrm{DQAA}^{10} 103$ DQB ${ }^{10502}$ & Caucasian & 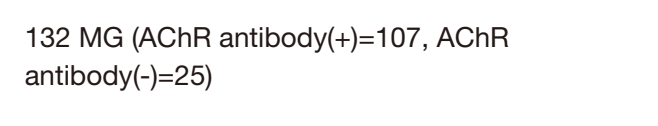 & 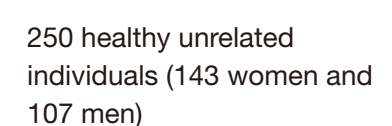 & 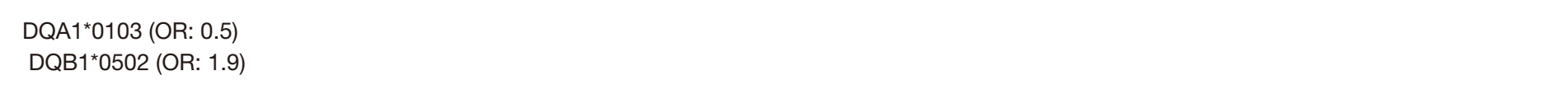 \\
\hline 27181991 & $\begin{array}{c}\text { Saruhan-Direskeneli } \\
G(3)\end{array}$ & $\begin{array}{l}\text { HLA Class I } \\
\text { region }\end{array}$ & is 113519545 & Turkic & 211 ЕOMG & $541 \mathrm{HC}$ & $P=2.24 \times 10^{-18}, 01,1,571(13.77-8.66)$ \\
\hline 27181991 & 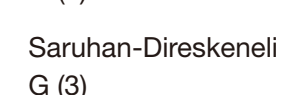 & $\begin{array}{l}\text { HLA class II } \\
\text { region }\end{array}$ & rst11256513 & Turkic & 109 LoMG & ${ }_{541 \mathrm{HC}}$ & $P=2.48 \times 10^{6}, \mathrm{C}, 1.222(1.59-3.09)$ \\
\hline 27181999 & $\begin{array}{l}\text { Saruhan-Direskeneil } \\
\text { G(r. }\end{array}$ & HLA-DOB1 & ${ }^{1588081734}$ & Turkic & 78 мusk-MG & $54 \mathrm{HC}$ & $P=2.25 \times 10^{-1,}, 0,1,58(3(3.72-9.22)$ \\
\hline 8964894 & Hielemström P (94) & HLA-DQB1 & DQB'10201 & Caucasian & 79 ма & $155 \mathrm{HC}$ & $P<0.05,0 R=3.73$ \\
\hline 19793653 & $\operatorname{PalZ}(95)$ & ORA & 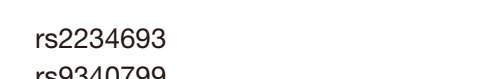 & Caucasian women & 113 female myasthenia patients & 184 female $\mathrm{HC}$ & $P>0.05$ \\
\hline 18037500 & Sakthivel P (96) & PDCD1 & r87565639 & Sweden & $269 \mathrm{MG}$ & 275 & Significant increa. \\
\hline $\begin{array}{l}24719132 \\
22617007\end{array}$ & $\begin{array}{l}\text { Na S S (97) } \\
\text { Kokunai (98) }\end{array}$ & $\begin{array}{l}\text { SLAMF } 1 \\
\text { SCNAA }\end{array}$ & $\begin{array}{l}\text { rs3753381 } \\
\text { G12920 }\end{array}$ & $\begin{array}{l}\text { Korean } \\
\text { Swedish Caucasian }\end{array}$ & $\begin{array}{l}55 \mathrm{AChR} \text { antibody positive } \mathrm{MG} \\
1 \text { acquired autoimmune myasthenia gravis }\end{array}$ & ${ }^{150 \mathrm{HC}}$ & $\begin{array}{l}P=9.6391 \times 10^{6} \\
P<0.05\end{array}$ \\
\hline 26632886 & Nel M (99) & TGFBT & $-387 \mathrm{C}>\mathrm{T}$ & African & OP-MG & 1000 & \\
\hline 24959269 & Zheng $\mathrm{K}(100)$ & $T M 1$ & $-1637 \mathrm{AG}$ & Chinese & $58 \mathrm{MG}(+)$ thymoma & 62 & Thymoma (MG+) vs. Thymoma (MG+), $\mathrm{P}=0.031$ \\
\hline 40035366 & Zheng, K. (101) & $T M T$ & $-1637 \mathrm{AG}$ & & 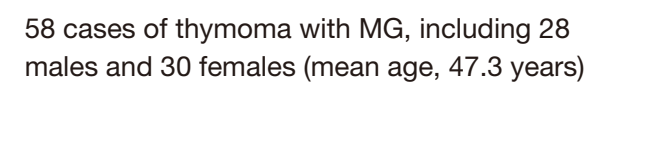 & 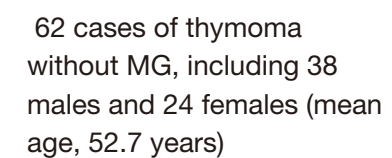 & \\
\hline 25663933 & $\times \cup G(102)$ & тмз & $\begin{array}{l}\text { GTrT genotype and Tallel on the } \\
\text {-577 lous }\end{array}$ & $\begin{array}{l}\text { Han population of Noth } \\
\text { China }\end{array}$ & 116 patients with hymmoma and MG & $\begin{array}{l}124 \text { patients with thymoma, } \\
\text { but withoumG }\end{array}$ & 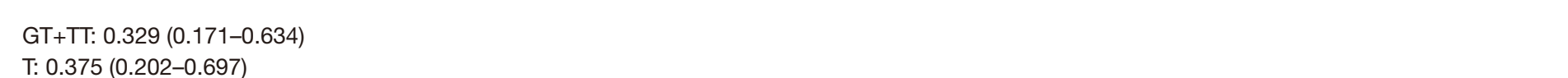 \\
\hline $\begin{array}{l}16075747 \\
10376950\end{array}$ & $\begin{array}{l}\text { Guan YZ(103) } \\
\text { Huang DR (104) }\end{array}$ & $\begin{array}{l}{ }_{T N F} \\
T N F\end{array}$ & $\begin{array}{l}-308 \mathrm{AA} \\
\text { TNF- }-308 \text { allete } 2\end{array}$ & $\begin{array}{l}\text { Chinese } \\
\text { Swedish caucasian }\end{array}$ & $\begin{array}{l}20 \mathrm{MG} \\
19 \mathrm{MG} \text { patients, Serum AChR-AB(F)=13.8\% }\end{array}$ & $\begin{array}{l}20 \\
100 \text { ethrically mat }\end{array}$ & LOMG patients (age > >4) compared to controls $(P<0.05)$ \\
\hline & & & & & 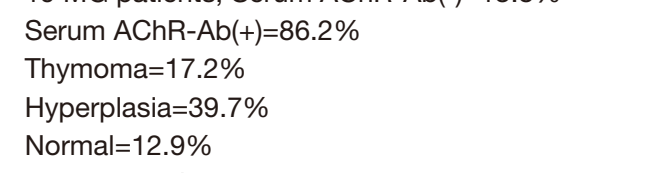 & heathy individus & \\
\hline 225142924 & Vang, Hong-Wei & TNFAAP3 & rs 7749323 & ${ }_{47}$ & 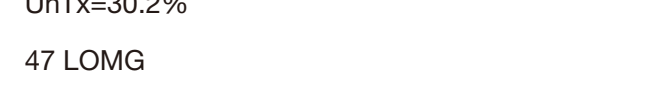 & 235 & $\mathrm{OR}=3.27,95 \% \mathrm{Cl}, 1.01-10.6, \mathrm{P}=0.04$ \\
\hline 9949945 & Zelano G (106) & TNFB & $\mathrm{TNFB}^{\mathrm{T}}$ & thaly & 63 MG patients Hyperplasia =26; thymoma = 17; & 93 heathy individuals & 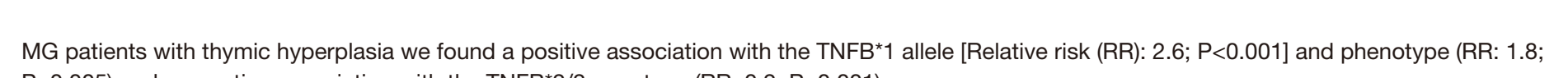 \\
\hline & & & & & 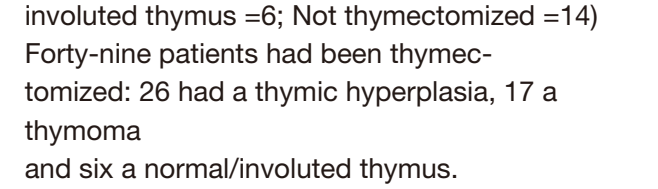 & & 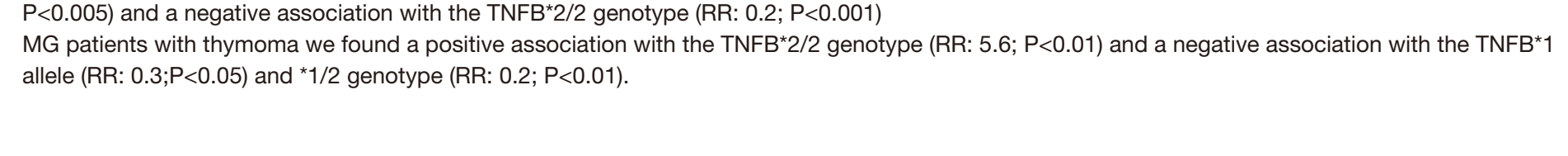 \\
\hline 9688335 & Hijelmström P (107) & TNFB & & Swedish Caucasian & 79 MG (51 females and 28 males $)$ & 155 unrelated healthy & 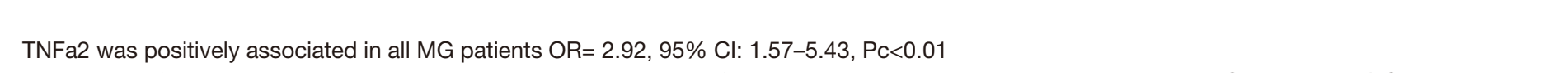 \\
\hline & & & 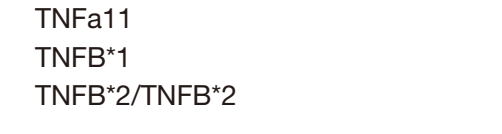 & & & & 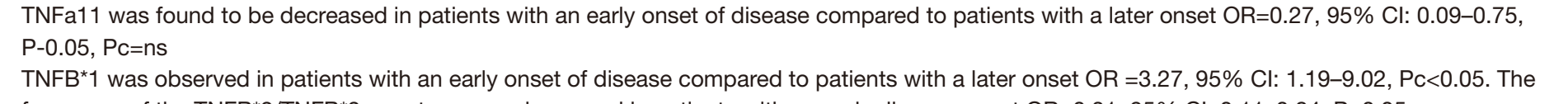 \\
\hline 23253802 & Han JL (108) & VDR & s757343 & Chinese & $302 \mathrm{MG}$ & ${ }_{283}$ & $\begin{array}{l}1.70(1.07-3.41) \\
1\end{array}$ \\
\hline
\end{tabular}


Table S3 Reported differentially expressed mircoRNAs in PBMC or serum in between MG cases and healthy controls

\begin{tabular}{|c|c|c|c|c|c|c|c|}
\hline PMID & Authors & MG subtype & miRNAs & PBMC or serum & $\begin{array}{c}\text { Ethnic group or } \\
\text { descent }\end{array}$ & Fold changes & $P$ value \\
\hline 22835429 & Lin Jiang (109) & MG & let-7a & PBMC & Chinese & -41.40 & $P<0.0001$ \\
\hline 22835429 & Lin Jiang (109) & & let-7b & PBMC & Chinese & -28.90 & $P<0.0001$ \\
\hline 22835429 & Lin Jiang (109) & & let-7c & PBMC & Chinese & -52.20 & $P<0.0001$ \\
\hline 22835429 & Lin Jiang (109) & & let-7d & PBMC & Chinese & -33.50 & $P<0.0001$ \\
\hline 24962817 & Zhangq J (110) & AChR-MG & miR-146a & PBMC & Chinese & 4.00 & $P<0.0100$ \\
\hline 24036458 & Lu J (111) & AChR-MG & $\mathrm{miR}-146 \mathrm{a}$ & B cell & Chinese & 3.5 & $P<0.0100$ \\
\hline 24043548 & Wang J (112) & EAMG & miR-145 & PBMC & Chinese & -0.28 & 0.0130 \\
\hline 24387321 & Wang (113) & EAMG & miR-155 & PBMC & Chinese & 8.00 & $P<0.0010$ \\
\hline 24637658 & Gisela Nogales-Gadea (114) & EOMG & $\mathrm{miR}-15 \mathrm{~b}$ & Serum & Turkey & -37.13 & $P<0.0230$ \\
\hline 24637658 & Gisela Nogales-Gadea (114) & LOMG & miR-122 & Serum & Turkey & -311.05 & $P<0.0010$ \\
\hline 24637658 & Gisela Nogales-Gadea (114) & LOMG & miR-140-3p & Serum & Turkey & -60.60 & $P<0.0040$ \\
\hline 24637658 & Gisela Nogales-Gadea (114) & LOMG & miR-185 & Serum & Turkey & -32.45 & 0.0020 \\
\hline 24637658 & Gisela Nogales-Gadea (114) & EOMG & miR-192 & Serum & Turkey & -57.62 & 0.0200 \\
\hline 24637658 & Gisela Nogales-Gadea (114) & EOMG & miR-20b & Serum & Turkey & -4.48 & 0.0330 \\
\hline 24637658 & Gisela Nogales-Gadea (114) & LOMG & miR-885-5p & Serum & Turkey & -148.66 & 0.0140 \\
\hline 23196978 & Zhuoan Cheng (115) & MG & miR-320a & Serum & Chinese & -7.1428 & 0.0433 \\
\hline \multirow[t]{3}{*}{25356381} & Tanel punga (116) & AChR-MG & miR-150-5p & Serum & Swedish & 13.2 & 0.002 \\
\hline & & & miR-21-5p & & & 3.3 & 0.011 \\
\hline & & & miR-27a-3p & & & -5.8 & 0.044 \\
\hline 3992033 & Wang (117) & MG & MiR-155 & PBMCs & Chinese & 5.8 & $\mathrm{P}<0.05$ \\
\hline 26845056 & Nie Chunjie (118) & MG & miR-20b & Serum & Chinese & 0.6 & $P<0.05$ \\
\hline 25962782 & Yong Zhang (119) & $\begin{array}{c}\text { Ocular } \\
\text { generalized }\end{array}$ & miR-181c & PBMCs & Chinese & $\begin{array}{l}0.25 \\
0.45\end{array}$ & $\begin{array}{l}P<0.01 \\
P<0.01\end{array}$ \\
\hline 26943954 & Tanel Punga (120) & MuSK+ MG & $\begin{array}{c}\text { miR-151a-3p } \\
\text { let-7f-5p } \\
\text { miR-423-5p } \\
\text { let-7d-3p } \\
\text { let-7a-5p } \\
\text { miR-409-3p }\end{array}$ & Serum & Roman & $\begin{array}{l}2.63 \\
3.76 \\
4.30 \\
3.68 \\
2.03 \\
4.46\end{array}$ & $\begin{array}{c}0.000887 \\
0.01040 \\
0.0118 \\
0.0178 \\
0.0327 \\
0.0351\end{array}$ \\
\hline 26095457 & Punga AR (121) & MG & $\begin{array}{l}\text { miR-150-5p } \\
\text { miR-21-5p }\end{array}$ & Serum & Swedish & $\begin{array}{l}2.7 \\
1.94\end{array}$ & $\begin{array}{l}P<0.0001 \\
P<0.0001\end{array}$ \\
\hline
\end{tabular}

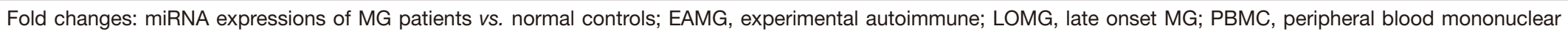
cell. 


\section{References}

39. Hong Y, Skeie GO, Zisimopoulou P, et al. Juvenile-onset myasthenia gravis: autoantibody status, clinical characteristics and genetic polymorphisms. J Neurol 2017;264:955-62.

40. Xu BY, Huang D, Pirskanen R, et al. beta2-adrenergic receptor gene polymorphisms in myasthenia gravis (MG). Clin Exp Immunol 2000;119:156-60.

41. Wang L, Zhang Y, He M. beta2-Adrenergic receptor gene polymorphisms in the relapse of myasthenia gravis with thymus abnormality. Int J Neurosci 2017;127:291-8.

42. Degli-Esposti MA, Leelayuwat C, Dawkins RL. Ancestral haplotypes carry haplotypic and haplospecific polymorphisms of BAT1: possible relevance to autoimmune disease. Eur J Immunogenet 1992;19:121-7.

43. Kim HS, Kim DS, Lee EY, et al. CCR2-64I and CCR5Delta32 Polymorphisms in Korean Patients with Myasthenia Gravis. J Clin Neurol 2007;3:133-8.

44. Wang XB, Kakoulidou M, Qiu Q, et al. CDS1 and promoter single nucleotide polymorphisms of the CTLA-4 gene in human myasthenia gravis. Genes Immun 2002;3:46-9.

45. Chuang WY, Strobel P, Gold R, et al. A CTLA4high genotype is associated with myasthenia gravis in thymoma patients. Ann Neurol 2005;58:644-8.

46. Wang XB, Pirskanen R, Giscombe R, et al. Two SNPs in the promoter region of the CTLA-4 gene affect binding of transcription factors and are associated with human myasthenia gravis. J Intern Med 2008;263:61-9.

47. Chuang WY, Strobel P, Bohlender-Willke AL, et al. Late-onset myasthenia gravis - CTLA4(low) genotype association and lowfor-age thymic output of naive T cells. J Autoimmun 2014;52:122-9.

48. Fernandez-Mestre M, Sanchez K, Balbas O, et al. Influence of CTLA-4 gene polymorphism in autoimmune and infectious diseases. Hum Immunol 2009;70:532-5.

49. Gu M, Kakoulidou M, Giscombe R, et al. Identification of CTLA-4 isoforms produced by alternative splicing and their association with myasthenia gravis. Clin Immunol 2008;128:374-81.

50. Wang XB, Kakoulidou M, Giscombe R, et al. Abnormal expression of CTLA-4 by T cells from patients with myasthenia gravis: effect of an AT-rich gene sequence. J Neuroimmunol 2002;130:224-32.

51. Renton AE, Pliner HA, Provenzano C, et al. A genome-wide association study of myasthenia gravis. JAMA Neurol 2015;72:396404.

52. Sun L, Meng Y, Xie Y, et al. CTLA4 variants and haplotype contribute genetic susceptibility to myasthenia gravis in northern Chinese population. PLoS One 2014;9:e101986.

53. Ligers A, Teleshova N, Masterman T, et al. CTLA-4 gene expression is influenced by promoter and exon 1 polymorphisms. Genes Immun 2001;2:145-52.

54. Franciotta D, Cuccia M, Dondi E, et al. Polymorphic markers in MHC class II/III region: a study on Italian patients with myasthenia gravis. J Neurol Sci 2001;190:11-6.

55. Ramanujam R, Zhao Y, Pirskanen R, et al. Lack of association of the CIITA -168A-->G promoter SNP with myasthenia gravis and its role in autoimmunity. BMC Med Genet 2010;11:147.

56. Garchon HJ, Djabiri F, Viard JP, et al. Involvement of human muscle acetylcholine receptor alpha-subunit gene (CHRNA) in susceptibility to myasthenia gravis. Proc Natl Acad Sci U S A 1994;91:4668-72.

57. Giraud M, Taubert R, Vandiedonck C, et al. An IRF8-binding promoter variant and AIRE control CHRNA1 promiscuous expression in thymus. Nature 2007;448:934-7.

58. Giraud M, Eymard B, Tranchant C, et al. Association of the gene encoding the delta-subunit of the muscle acetylcholine receptor (CHRND) with acquired autoimmune myasthenia gravis. Genes and Immunity 2004;5:80-3.

59. Viken MK, Sollid HD, Joner G, et al. Polymorphisms in the cathepsin L2 (CTSL2) gene show association with type 1 diabetes and early-onset myasthenia gravis. Hum Immunol 2007;68:748-55.

60. Heckmann JM, Uwimpuhwe H, Ballo R, et al. A functional SNP in the regulatory region of the decay-accelerating factor gene associates with extraocular muscle pareses in myasthenia gravis. Genes Immun 2010;11:1-10.

61. Landoure G, Knight MA, Stanescu H, et al. A candidate gene for autoimmune myasthenia gravis. Neurology 2012;79:342-7.

62. van der Pol WL, Jansen MD, Kuks JB, et al. Association of the Fc gamma receptor IIA-R/R131 genotype with myasthenia 
gravis in Dutch patients. J Neuroimmunol 2003;144:143-7.

63. Raknes G, Skeie GO, Gilhus NE, et al. FcgammaRIIA and FcgammaRIIIB polymorphisms in myasthenia gravis. J Neuroimmunol 1998;81:173-6.

64. Zhang J, Chen Y, Jia G, et al. FOXP3 -3279 and IVS9+459 polymorphisms are associated with genetic susceptibility to myasthenia gravis. Neurosci Lett 2013;534:274-8.

65. Chuang WY, Strobel P, Belharazem D, et al. The PTPN22gain-of-function+1858T(+) genotypes correlate with low IL-2 expression in thymomas and predispose to myasthenia gravis. Genes Immun 2009;10:667-72.

66. Greve B, Hoffmann P, Illes Z, et al. The autoimmunity-related polymorphism PTPN22 1858C/T is associated with anti-titin antibody-positive myasthenia gravis. Hum Immunol 2009;70:540-2.

67. Lefvert AK, Zhao Y, Ramanujam R, et al. PTPN22 R620W promotes production of anti-AChR autoantibodies and IL-2 in myasthenia gravis. J Neuroimmunol 2008;197:110-3.

68. Kaya GA, Coskun AN, Yilmaz V, et al. The Association of PTPN22 R620W Polymorphism Is Stronger with Late-Onset AChR-Myasthenia Gravis in Turkey. Plos One 2014;9.

69. Vandiedonck C, Capdevielle C, Giraud M, et al. Association of the PTPN22*R620W polymorphism with autoimmune myasthenia gravis. Ann Neurol 2006;59:404-7.

70. Provenzano C, Ricciardi R, Scuderi F, et al. PTPN22 and myasthenia gravis: replication in an Italian population and metaanalysis of literature data. Neuromuscul Disord 2012;22:131-8.

71. Xiong X, Xiang M, Cheng X, et al. PTPN22 R620W Polymorphism is Associated with Myasthenia Gravis Risk: A Systematic Review and Meta-Analysis. Med Sci Monit 2015;21:2567-71.

72. Zheng J, Ibrahim S, Petersen F, et al. Meta-analysis reveals an association of PTPN22 C1858T with autoimmune diseases, which depends on the localization of the affected tissue. Genes Immun 2012;13:641-52.

73. Gregersen PK, Kosoy R, Lee AT, et al. Risk for myasthenia gravis maps to a (151) Pro-->Ala change in TNIP1 and to human leukocyte antigen- $\mathrm{B}^{*} 08$. Ann Neurol 2012;72:927-35.

74. Yilmaz V, Tutuncu Y, Baris Hasbal N, et al. Polymorphisms of interferon-gamma, interleukin-10, and interleukin-12 genes in myasthenia gravis. Hum Immunol 2007;68:544-9.

75. Yang LL, Wang JJ, Sun XS, et al. Identifying a Polymorphic 'Switch' That Influences miRNAs' Regulation of a Myasthenia Gravis Risk Pathway. Plos One 2014;9.

76. Pal Z, Varga Z, Semsei A, et al. Interleukin-4 receptor alpha polymorphisms in autoimmune myasthenia gravis in a Caucasian population. Hum Immunol 2012;73:193-5.

77. Sciacca FL, Ferri C, Veglia F, et al. IL-1 genes in myasthenia gravis: IL-1A -889 polymorphism associated with sex and age of disease onset. J Neuroimmunol 2002;122:94-9.

78. Huang D, Pirskanen R, Hjelmstrom P, et al. Polymorphisms in IL-1beta and IL-1 receptor antagonist genes are associated with myasthenia gravis. J Neuroimmunol 1998;81:76-81.

79. Huang D, Zheng C, Giscombe R, et al. Polymorphisms at - 174 and in the 3' flanking region of interleukin-6 (IL-6) gene in patients with myasthenia gravis. Journal of neuroimmunology 1999;101:197-200.

80. Huang DR, Zhou YH, Xia SQ, et al. Markers in the promoter region of interleukin-10 (IL-10) gene in myasthenia gravis: implications of diverse effects of IL-10 in the pathogenesis of the disease. J Neuroimmunol 1999;94:82-7.

81. Zagoriti Z, Georgitsi M, Giannakopoulou O, et al. Genetics of myasthenia gravis: a case-control association study in the Hellenic population. Clin Dev Immunol 2012;2012:484919.

82. Alseth EH, Nakkestad HL, Aarseth J, et al. Interleukin-10 promoter polymorphisms in myasthenia gravis. J Neuroimmunol 2009;210:63-6.

83. Yue YX, Hong Y, Xie Y, et al. Association study between IL-17A and IL-17F gene polymorphism and myasthenia gravis in Chinese patients. Neurol Sci 2016;37:123-30.

84. Pal Z, Antal P, Millinghoffer A, et al. A novel galectin-1 and interleukin 2 receptor beta haplotype is associated with autoimmune myasthenia gravis. J Neuroimmunol 2010;229:107-11.

85. Pal Z, Antal P, Srivastava SK, et al. Non-synonymous single nucleotide polymorphisms in genes for immunoregulatory galectins: association of galectin-8 (F19Y) occurrence with autoimmune diseases in a Caucasian population. Biochim Biophys Acta 2012;1820:1512-8. 
86. Kellermayer B, Polgar N, Pal J, et al. Association of myasthenia gravis with polymorphisms in the gene of histamine N-methyltransferase. Hum Immunol 2013;74:1701-4.

87. Fekih-Mrissa N, Klai S, Zaouali J, et al. Association of HLA-DR/DQ polymorphism with myasthenia gravis in Tunisian patients. Clin Neurol Neurosurg 2013;115:32-6.

88. Zhu WH, Lu JH, Lin J, et al. HLA-DQA1*03:02/DQB1*03:03:02 is strongly associated with susceptibility to childhood-onset ocular myasthenia gravis in Southern Han Chinese. J Neuroimmunol 2012;247:81-5.

89. Yang H, Hao J, Peng X, et al. The association of HLA-DQA1*0401 and DQB1*0604 with thymomatous myasthenia gravis in northern Chinese patients. J Neurol Sci 2012;312:57-61.

90. Testi M, Terracciano C, Guagnano A, et al. Association of HLA-DQB1 *05:02 and DRB1 *16 Alleles with Late-Onset, Nonthymomatous, AChR-Ab-Positive Myasthenia Gravis. Autoimmune Dis 2012;2012:541760.

91. Hajeer AH, Sawidan FA, Bohlega S, et al. HLA class I and class II polymorphisms in Saudi patients with myasthenia gravis. Int J Immunogenet 2009;36:169-72.

92. Yousefipour GA, Salami Z, Farjadian S. Association of HLA-DQA1*0101/2 and DQB1*0502 with myasthenia gravis in southern Iranian patients. Iran J Immunol 2009;6:99-102.

93. Saruhan-Direskeneli G, Kilic A, Parman Y, et al. HLA-DQ polymorphism in Turkish patients with myasthenia gravis. Hum Immunol 2006;67:352-8.

94. Hjelmstrom P, Giscombe R, Lefvert AK, et al. Polymorphic amino acid domains of the HLA-DQ molecule are associated with disease heterogeneity in myasthenia gravis. J Neuroimmunol 1996;65:125-31.

95. Pal Z, Gal A, Remenyi V, et al. Oestrogen receptor alpha gene intronic polymorphisms and autoimmune myasthenia gravis in Caucasian women. Neuromuscul Disord 2009;19:822-4.

96. Sakthivel P, Ramanujam R, Wang XB, et al. Programmed Death-1: from gene to protein in autoimmune human myasthenia gravis. J Neuroimmunol 2008;193:149-55.

97. Na SJ, Lee JH, Kim SW, et al. Whole-genome analysis in Korean patients with autoimmune myasthenia gravis. Yonsei Med J 2014;55:660-8.

98. Kokunai Y, Goto K, Kubota T, et al. A sodium channel myotonia due to a novel SCN4A mutation accompanied by acquired autoimmune myasthenia gravis. Neurosci Lett 2012;519:67-72.

99. Nel M, Buys JM, Rautenbach R, et al. The African-387 C>T TGFB1 variant is functional and associates with the ophthalmoplegic complication in juvenile myasthenia gravis. J Hum Genet 2015.

100.Zheng K, Xu GW, Lu X, et al. Expression and polymorphisms of T cell immunoglobulin domain and mucin domain protein-1 in thymoma with or without myasthenia gravis. Oncology Letters 2014;8:317-22.

101.Zheng K, Xu G, Lu X, et al. Expression and polymorphisms of T cell immunoglobulin domain and mucin domain protein-1 in thymoma with or without myasthenia gravis. Oncol Lett 2014;8:317-22.

102.Xu G, Zheng $\mathrm{K}$, Lu X, et al. Association between polymorphisms in the promoter region of $\mathrm{T}$ cell immunoglobulin and mucin domain-3 and myasthenia gravis-associated thymoma. Oncol Lett 2015;9:1470-4.

103. Guan YZ, Cui LY, Li YF, et al. Tumor necrosis factor-alpha polymorphism and secretion in myasthenia gravis. Chin Med Sci J 2005;20:104-7.

104.Huang DR, Pirskanen R, Matell G, et al. Tumour necrosis factor-alpha polymorphism and secretion in myasthenia gravis. J Neuroimmunol 1999;94:165-71.

105. Yang HW, Xie Y, Zhao Y, et al. TNFAIP3 gene rs7749323 polymorphism is associated with late onset myasthenia gravis. Medicine (Baltimore) 2017;96:e6798.

106.Zelano G, Lino MM, Evoli A, et al. Tumour necrosis factor beta gene polymorphisms in myasthenia gravis. Eur J Immunogenet 1998;25:403-8.

107.Hjelmstrom P, Peacock CS, Giscombe R, et al. Polymorphism in tumor necrosis factor genes associated with myasthenia gravis. J Neuroimmunol 1998;88:137-43.

108. Han J, Li H, Xie Y, et al. [Association between vitamin D receptor gene Tru9I polymorphism and myasthenia gravis]. Zhonghua yi xue za zhi 2012;92:2028-33.

109.Jiang L, Cheng Z, Qiu S, et al. Altered let-7 expression in Myasthenia gravis and let-7c mediated regulation of IL-10 by directly targeting IL-10 in Jurkat cells. Int Immunopharmacol 2012;14:217-23. 
110.Zhang J, Jia G, Liu Q, et al. Silencing miR-146a influences B cells and ameliorates experimental autoimmune myasthenia gravis. Immunology 2015;144:56-67.

111.Lu J, Yan M, Wang Y, et al. Altered expression of miR-146a in myasthenia gravis. Neurosci Lett 2013;555:85-90.

112.Wang J, Zheng S, Xin N, et al. Identification of novel MicroRNA signatures linked to experimental autoimmune myasthenia gravis pathogenesis: down-regulated miR-145 promotes pathogenetic Th17 cell response. J Neuroimmune Pharmacol 2013;8:1287-302.

113.Wang YZ, Tian FF, Yan M, et al. Delivery of an miR155 inhibitor by anti-CD20 single-chain antibody into B cells reduces the acetylcholine receptor-specific autoantibodies and ameliorates experimental autoimmune myasthenia gravis. Clinical and Experimental Immunology 2014;176:207-21.

114. Nogales-Gadea G, Ramos-Fransi A, Suarez-Calvet X, et al. Analysis of serum miRNA profiles of myasthenia gravis patients. PLoS One 2014;9:e91927.

115. Cheng ZA, Qiu SB, Jiang L, et al. MiR-320a is Downregulated in Patients with Myasthenia Gravis and Modulates Inflammatory Cytokines Production by Targeting Mitogen-activated Protein Kinase 1. Journal of Clinical Immunology 2013;33:567-76.

116. Punga T, Le Panse R, Andersson M, et al. Circulating miRNAs in myasthenia gravis: miR-150-5p as a new potential biomarker. Ann Clin Transl Neurol 2014;1:49-58.

117.Wang YZ, Tian FF, Yan M, et al. Delivery of an miR155 inhibitor by anti-CD20 single-chain antibody into B cells reduces the acetylcholine receptor-specific autoantibodies and ameliorates experimental autoimmune myasthenia gravis. Clin Exp Immunol 2014;176:207-21.

118. Chunjie N, Huijuan N, Zhao Y, et al. Disease-specific signature of serum miR-20b and its targets IL-8 and IL-25, in myasthenia gravis patients. Eur Cytokine Netw 2015;26:61-6.

119.Zhang Y, Guo M, Xin N, et al. Decreased microRNA miR-181c expression in peripheral blood mononuclear cells correlates with elevated serum levels of IL-7 and IL-17 in patients with myasthenia gravis. Clin Exp Med 2016;16:413-21.

120.Punga T, Bartoccioni E, Lewandowska M, et al. Disease specific enrichment of circulating let-7 family microRNA in MuSK+ myasthenia gravis. J Neuroimmunol 2016;292:21-6.

121.Punga AR, Andersson M, Alimohammadi $M$, et al. Disease specific signature of circulating miR-150-5p and miR-21-5p in myasthenia gravis patients. J Neurol Sci 2015;356:90-6. 